\title{
GENEZEN ALS GOED DOEN
}

\section{ERIC OTTENHEIJM}

To cite this article: ERIC OTTENHEIJM (2002) GENEZEN ALS GOED DOEN, Bijdragen, 63:3, 335-366, DOI: 10.2143/BIJ.63.3.814

To link to this article: https://doi.org/10.2143/BIJ.63.3.814

曲 Published online: 25 Apr 2013.

Submit your article to this journal $\pi$

Џلll Article views: 13

Q View related articles $匚$ 


\section{GENEZEN ALS GOED DOEN}

\section{HALACHISCHE LOGICA IN MT 12, 9-14}

\section{ERIC OTTENHEIJM}

De sjabbat biedt een sleutel bij uitstek om Jezus' omgang met de Mozaïsche wet te typeren. Het houden van de sjabbat is immers niet alleen een centraal, bijbels gebod maar bovendien, zeker in de Tweede Tempelperiode, identiteitsmarkerend. ${ }^{1}$

Een klassiek en nog immer vigerend oordeel in de exegese luidt, dat Jezus de sjabbatswetten onder fundamentele kritiek stelt en dat hij met zijn wetsopvatting min of meer buiten de kaders valt van het toenmalige Jodendom. ${ }^{2}$ Men verwijst dan naar de synoptische disputen over de sjabbat. ${ }^{3}$ Maar dat oordeel is, gegeven de eveneens aanwezige neutrale en positieve referenties aan de sjabbat, problematisch. ${ }^{4}$ Die referenties roepen veeleer een sfeer op van vanzelfsprekendheid, een klimaat waarin de sjabbat als positieve realiteit is voorondersteld. Cruciaal is dat ook disputen niet noodzakelijk wijzen op een afstand tot de wet. De Tweede Tempelperiode kenmerkt zich juist door een zich ontwikkelende en pluriforme wetgeving rond de sjabbat. ${ }^{5}$ Zowel tussen

1 T.G. Eshkenazi (ed.), The Sabbath in Jewish and Christian Traditions, New York 1991. H. Weiss, 'The Sabbath in the Writings of Josephus', JSJ 29/4 (1998) pp. 363-390; H. Weiss, 'Philo and the Sabbath', in: Heirs of the Septuagint. Studia Philonica Annual 3 (1992) pp. 91-92; E.P. Sanders, Jewish Law from Jesus to the Mishnah. Five Studies, London/Philadelphia 1990, pp. 21 e.v.

${ }^{2}$ Sommige auteurs zien hierin, in navolging van Bultmann, vooral gemeentetheologie, maar dat is voor hun eindoordeel irrelevant.

${ }^{3}$ Een goed overzicht biedt Sven Olav Back, Jesus of Nazareth and the Sabbath Commandment, Åbo 1995, pp. 1-16.

${ }^{4}$ H. Weiss, 'The Sabbath in the New Testament', JSNT 38 (1990) pp. 13-27.

${ }^{5}$ Daarop wijst bijvoorbeeld de frappante overeenkomst tussen Mk 2,27 en de Mechilta deRabbi Isjmael op Ex 31,15 (ed. Horowitz/Rabin p. 343), beiden in de context van levensredding op sjabbat. Overigens sluit de wetvergelijkende benadering de redaktiekritische (met haar vraag naar de theologie van de redactor) en Formgeschichtlichte benadering (met haar vraag naar de invloed van de vroege gemeentes) niet uit. Zie Ulrich Luz, Das Evangelium nach Matthäus (Mt 8-17). EvangelischKatholischer Kommentar zum Neuen Testament 1/2, 1990 (3., durchgesehene Auflage 1999), Neukirchen/Vluyn 1999 en Back, Sabbath Commandment; Lutz Doering, Schabbat. Sabbathalacha 
verschillende Joodse groeperingen - zoals Qumran en haar Farizeese opponenten - als binnen de Farizeese beweging zelf stuiten we in dat verband veelvuldig op (wets)disputen. Disputen wijzen, kortom, niet bij voorbaat op een breuk met het toenmalige Jodendom. ${ }^{6}$

Deze studie wil in dat perspectief een bijdrage leveren aan het onderzoek naar Mt 12,9-14, de man met de verstijfde hand. In die perikoop (par. Mc 3,1-6/ Lc 6, 6-11) ${ }^{7}$ wordt Jezus de vraag gesteld 'of het is toegestaan te genezen op sjabbat' (vs. 10). Volgens Mattheïs dient hij zijn vragenstellers van repliek in drie fasen. Hij presenteert de casus van iemand die één schaap heeft dat in een put terecht komt op sjabbat (vs. 11). Vervolgens trekt hij de conclusie dat 'het is toegestaan goed te doen op sjabbat' (vs. 12b). Daarop volgt de genezing (vs. 13), die behelst dat hij de man vraagt zijn hand uit te strekken en deze hand dan blijkt te zijn 'zoals de andere'.

Het grootste struikelblok in het onderzoek is gelegen in de relatie tussen de vraag van de omstanders naar het 'genezen' en het antwoord van Jezus dat het is toegestaan 'goed te doen'. ${ }^{8}$ Men slaagt er vooralsnog niet in, die overgang op een bevredigende wijze te verklaren. Ook het wetvergelijkende onderzoek valt terug op een kritiek van Jezus op de halacha. ${ }^{9}$ De meest radicale opvatting

und -praxis im antiken Judentum und Urchristentum. Texts and Studies in Ancient Judaism 78, Tübingen 1999. Doering concludeert o.m.: 'Die unterschiedliche Realisierung des Gebots in den verschiedenen Gruppen und Kreisen hat zur je charakterischen Mischung von auf breiterem Konsenz beruhender und gruppenspezifischer Sabbathalacha geführt.' (575) Een zelfde spoor, zij het met minder diepgang, volgt Yong-Eui Yang, Jesus and the Sabbath in Matthew's Gospel. JSNT Suppl. Ser. 139, Sheffield 1997. Niettemin valt hij voor de disputen terug op een christocentrische uitleg: Jezus heeft de eschatologische bedoeling van de sjabbat vervuld ('proleptic presence of the 'rest' of the age to come', p. 499). Zo zou iedere vorm van legalisme (!) in de gemeente de pas worden afgesneden. De tegenstelling tussen de wet van de Farizeeën en de eigenlijke bedoeling van de wet, zichtbaar in Jezus' handelen, is, in het licht van de vele debatten over de wet, historisch onhoudbaar.

${ }^{6}$ A. Baumgarten, The Flourishing of Jewish Sects in the Maccabean Era: an Interpretation, Leiden 1997 toont aan, dat wetsdisputen op zichzelf nog niet leiden tot sectarisme. Voor de heuristische betekenis van controverses in de ontwikkeling van de tannaitische halacha, zie S. Safrai, 'Halakha', in: The Literature of the Sages, S. Safrai (ed.), Compendia Rerum Judaicarum ad Novum Testamentum ll, 3/1 (CRINT), Assen/Philadelphia 1987, pp. 168-175.

${ }^{7}$ Ofschoon er een thematische samenhang is met de voorafgaande perikoop over het plukken van de aren, legitimeert de narratieve en 'formgeschichtliche' eenheid van onze passage deze afgrenzing.

${ }^{8}$ Vergelijk Sanders, Jewish Law, p. 21: 'The principle is too vague and might mean anything.'

${ }^{9}$ Halacha is de rabbijnse term voor de praktisch-religieuze wet, zowel in haar theoretische aspect als in haar feitelijke aspect: ' $(.$.$) the sum total of rules and laws - derived from the Bible, from reli-$ gious thought and teaching, from jurisprudence and custom - that govern all aspects of Jewish life.': S. Safrai, 'Halakhah', in Literature of the Sages, p. 121. Volgens Safrai is de etymologie van het woord in het elfde eeuwse Arukh Completum, dat halacha afleidt van de stamvorm הלך, onjuist. Safrai wijst op de Aramese, juridische term הלכא הלך, dat een belasting op een stuk land 
luidt, dat Jezus' antwoord in vers 12 een fundamentele kritiek is op wettelijk denken, met een beroep op de 'wet' van de liefde. ${ }^{10}$ In deze opvatting klinkt nog de positie van J. Jeremias door, dat sjabbatsobservantie wordt bekritiseerd omdat die de vervulling van het liefdesgebod in de weg zou staan. ${ }^{11}$ Niettemin biedt deze these geen bevredigende oplossing voor de formele logica die Jezus hanteert (het a fortiori argument en de technische term 'toegestaan') en die wijst op een Joods wettelijk denken. Een genuanceerder oordeel biedt het commentaar van Luz. De perikoop beantwoordt formeel aan het kader van een wetsdispuut, maar inhoudelijk doorbreekt het dat kader waar het de liefde als overkoepelend beginsel leert. ${ }^{12}$ Luz erkent weliswaar de formeel-halachische

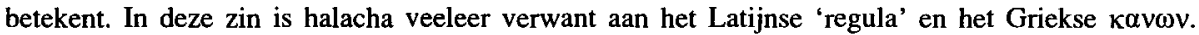
Ofschoon halacha strikt genomen het rabbijnse denksysteem vooronderstelt, hanteren veel auteurs de term in sociaal-religieuze zin voor niet-rabbijnse corpora. Zie bijvoorbeeld L. Schiffman, The Halakhah at Qumran, Leiden 1975. Kritiek op gebruik van deze term voor niet-rabbijnse bronnen is verwoord in N.A. van Uchelen, 'Halakhah at Qumran?', $R Q$ 70/18 (1997) pp. 243-253. Zie ook diens 'Halacha in het Nieuwe Testament?', NTT (1996) pp. 177-189, met een weerwoord van P.J. Tomson (pp. 190-193). Van Uchelen benadrukt het formeel-linguistische aspect van de rabbijnse halacha naar mijn smaak te zeer ten koste van de inhoudelijke en historische aspecten. Belangrijk lijkt me in dit verband de bemerking van Tomson, p. 192 dat linguistische verschillen samenhangen met sociaal-religieuze autoriteit in de ontwikkeling van de wet. Zie Baumgarten, Jewish Sects, pp. 78-79. De aan de bijbelse wetgeving herinnerende, apodictische vormen in Qumran weerspiegelen de absolute autoriteit van de Leraar der Gerechtigheid en diens uitleg van de Tora. De Rabbijnse halacha formuleert feitelijk of geidealiseerd gedrag van de gemeenschap en biedt rationele argumentaties of uiteenlopende Schriftuurlijke bewijsvoeringen. De nieuwtestamentische disputen markeren in die samenhang een bijzondere tussenvorm daar een ik-gezagsstructuur van Jezus voorkomt naast aan rabbijnse halacha verwante begrippen en denkstructuren, zoals ook uit onze passage blijkt.

10 Back, Sabbath Commandment, p.114 meent dat Marcus de vraag of het is toegestaan te genezen, omkeert in een kritiek op die vraag zelf: natuurlijk is het noodzakelijk op sjabbat te genezen. Back kan deze conclusie, volgens Doering, Schabbat, p. 450, n. 298 niet waarmaken. Back's conclusies liggen dicht aan tegen Stephen Smith, 'Mark 3,1-6: Form, Redaction and Community Function', Biblica 75 (1994) pp. 153-174. Volgens Smith beoogt de retorische vraag in Mc 3,3 te benadrukken, dat de realisering van het Koninkrijk Gods door de beperkingen heen breekt die de sjabbat oplegt.

11 J. Jeremias, Neutestamentliche Theologie, Tl 1, Gütersloh 1979, p. 202.

12 Luz, Matthäus, p. 239: 'Formal ist also 12b eine Halakha, nämlich die Grundregel der Sjabbatpraxis der Matthäischen Gemeinde. Inhaltlich geht es aber um eine grundsätzliche Unterordnung des Sjabbatgebotes unter die Liebe.' (cursivering van Luz). Scherper klinkt het waar Jezus 'überkommene jüdische Religiosität in eine Krise führte, indem er die Liebe provokativ in ihre Mitte stellte.' (p. 241) Genuanceerder A.J. Saldarini, Matthew's Christian Jewish Community, Chicago/ London 1994, p.133: 'Doing good in this case and in general means acting mercifully in as full a way as possible (sic!) because mercifull actions override the Sabbath. Thus Matthew enters into an open discussion concerning Sabbath observance with this very broad principle of doing good and practicing mercy.' Zoals we zullen zien zit Saldarini op een goed spoor waar hij het heeft over een 'clash of laws' (p. 131). Doering, Schabbat, p. 461 spreekt in navolging van Luz van een 'übergeordneten Perspektive'. 
toonzetting van het dispuut maar hij grijpt uiteindelijk terug op een dichotomie van (sjabbats)wetgeving en liefde. En ook hier dient zich de vraag aan, waarom een pleidooi voor liefde zich niettemin blijft bewegen in wettelijke, formele redeneringen.

Ik wil laten zien, dat een vergelijkend onderzoek met behulp van oude lagen in de rabbijnse literatuur, te weten de disputen tussen Bet Sjammai en Bet Hillel, ons helpt de 'halachische' logica in Mattheüs op het spoor te komen. Ook de literaire samenhang van het debat in Mattheüs blijkt hiermee inzichtelijker te worden. De samenhang van beide doelstellingen - logica en literaire samenhang - is bepalend voor de plausibiliteit van de in deze studie voorgestelde verklaring.

We zullen zien, dat het debat, inclusief de genezing, zowel formeel als inhoudelijk is te typeren als een discours over de status van 'goede werken' op sjabbat. De onderlinge hiërarchie van sjabbat en goede werken resulteert bij Mattheuis in een zekere relativering van de sjabbat. Maar dat neemt niet weg, dat de vraag met de daarin verwoorde spanning tussen geboden en goede werken zowel formeel als inhoudelijk is te plaatsen binnen de sfeer van de vroeg-Joodse halacha, verwant aan de Hillelitische factie binnen het farizeese Jodendom. Dat maakt Mt 12 tot een belangrijke getuige voor de ontwikkeling van de halacha. ${ }^{13}$ Bovendien zullen we zien, dat Mattheüs hierin een andere versie of uitleg van het dispuut biedt dan Marcus/Lucas.

We starten met een korte inleiding op het voor ons wetvergelijkende onderzoek relevante corpus disputaties tussen de Huizen van Sjammai en Hillel (par. 1). $\mathrm{Na}$ een synoptische (par. 2) en redactiekritische analyse van de Mattheaanse perikoop (par. 3) analyseren we het discours in wetvergelijkend perspectief (par. 4).

${ }^{13}$ Het voorkomen van Joodse overleveringen staat los van de vraag of de eindredactie van Mattheüs plaatsvond in een Joods-christelijke gemeente of vanuit een niet-Joods perspectief. De eerste opvatting verdedigt Saldarini, Matthew's Community. De tweede opvatting lijkt de meest gehuldigde: U. Luz, Mattheüs $/ 1$ ( (1-7). Evangelisch-Katholischer Kommentar zum Neuen Testament, $4^{c}$. durchgesehene Auflage, Neukirchen/Vluyn 1997, pp. 62-63. Zie ook P.J. Tomson, 'Als dit uit de hemel is...' Jezus en de schrijvers van het Nieuwe Testament in hun verhouding tot het Jodendom. Derde, gecorrigeerde druk, Hilversum 1997, pp. 235-236. Niet zozeer de felle antifarizeese polemieken (Mt 23) wijzen op niet-Joods perspectief. Soortgelijke motieven vinden we in polemieken in Qumran of de rabbijnse literatuur: Moshe Weinfeld, 'The Charge of Hypocrisy in Matthew 23 and in Jewish Sources', in: Immanuel 24/24 (1990) pp. 52-58. Belangrijker zijn de anti-Joodse redactie en het Mattheaanse gebruik van de terminologie 'Joden': David Flusser, 'Twee voorbeelden van antiJoodse redactie bij Mattheüs', in zijn Ontdekkingen in het Nieuwe Testament. Woorden van Jezus en hun overlevering, Baarn 1988, pp. 44-67; P.J. Tomson, 'The Names Israel and Jew in Ancient Judaism', Bijdragen 47 (1986) 120-140. 


\section{Bet Hillel, Bet Sjammai en hun sjabbatsdisputaties}

De rabbijnse literatuur bevat honderden disputaties op naam van Bet Sjammai en Bet Hillel, de Huizen van Sjammai en Hillel. Ofschoon informatie over samenstelling en aard van de Huizen nagenoeg ontbreekt, plaatst men hun optreden in de laatste decennia van de Tweede Tempelperiode. De traditionele identificatie van de Huizen met de Farizeeën van Josephus en het Nieuwe Testament is volgens enkele onderzoekers niet vanzelfsprekend. ${ }^{14}$ De rabbijnse literatuur is inderdaad zeer terughoudend en zelfs tegenstrijdig waar ze over Farizeeën komt te spreken en nergens worden de Huizen zelf met Farizeeën geïdentificeerd. ${ }^{15}$ Dat kan echter te maken hebben met de terughoudendheid om, na de desastreuze ervaringen van 66-70, de naam Farizeeër te gebruiken, die immers de klank had van religieus separatisme. ${ }^{16}$ Het is in dit verband van belang dat de belangrijkste bronnen voor onze kennis van de Farizeeën relatief tendentieus zijn. Dat geldt zeker voor de Farizeeën in de synoptische evangeliën. Josephus' portrettering van de Farizeeën hangt samen met zijn doel, het Jodendom te verdedigen voor een niet-Joods publiek, al wil dat niet zeggen dat zijn typeringen daarmee onjuist zijn. ${ }^{17} \mathrm{Bij}$ het ontbreken

14 Vergelijk de bijna terloopse opmerking in S. Cohen, 'The Significance of Yavneh. Pharisees, Rabbis and the End of Sectarianism', HUCA 55 (1984) pp. 27-53: 'This uncertainty applies to the Houses too.' (p 37, note 21; hij heeft overigens geen oplossing, noot 57). Lester L. Grabbe, '4QMMT and Second Temple Jewish Society', in: M. Bernstein/F. Garcia Martinez/J. Kampen (eds), Legal Texts and Legal Issues. Proceedings of the Second Meeting of the International Organization for Qumran Studies, Cambridge 1985. Studies on the Texts of the Desert of Judah vol. 23, Leiden 1998, pp. 104-107 stelt dat de Scholen geen politieke - of Tempelkwesties bespreken en dus niet identiek kunnen zijn met de Farizeeën van Josephus. Dat is niet geheel juist: enkele disputen tussen Hillel en Sjammai betreffen Tempelkwesties en de Huizen disputeren het sprenkelen van offerbloed (M. Zebahim 7,1). J. Neusner, The Rabbinic Traditions about the Pharisees before 70 ( 3 Vls), Leiden 1971 identificeert de Huizen als Farizeën maar is in zijn latere werk negatief over de continuiiteit tussen Farizecën en rabbijnen: Judaism: the Evidence of the Mishnah, Chicago 1981 en Das pharisaische und Talmudische Judentum. Neue Wege zu seinem Verständnis, Tübingen 1984. Een scherpe evaluatie van zijn veelvuldige, steeds polemischer getinte publicaties biedt $\mathrm{R}$. Deines, Die Pharisäer. Ihr Verständniss im Spiegel der christlichen und jüdischen Forschung seit Wellhausen und Graetz. WUNT 101, Tübingen 1997, pp. 534-538.

${ }^{15}$ Dat argument gaat op, wanneer de naam duidt op afgescheidenen. Vgl. G. Stemberger, Pharisäer, Sadduzäer, Essener, Stuttgarter Bibelstudien 144, Stuttgart 1991, pp. 110 en 113.

${ }^{16}$ Cohen, 'Significance', p. 41. Stemberger, Pharisäer, pp. 41-46 biedt afzonderlijke besprekingen van de relevante passages.

${ }_{17}$ P. Schäfer, 'Das vorrabbinische Pharisäismus', in: M. Hengel/U. Heckel (Hrsg.), Paulus und das antike Judentum, Tübingen 1991, pp. 125-176 vergelijkt de passages en is uiterst terughoudend in zijn historische conclusies. Minder sceptisch is S. Mason, Josephus and the New Testament, Massachusets 1992, pp. 131-148. De Farizeeën zijn zeker niet de favoriete partij voor Josephus, en 
van expliciete identificaties kunnen details van beslissende betekenis zijn. Zo is de identificatie van de Huizen als facties in het Farizeese Jodendom momenteel weer een serieuze hypothese, en wel op grond van 4QMMT, de 'halachische brief' uit Qumran. ${ }^{18} \mathrm{Ik}$ acht haar inderdaad de meest plausibele. In een andere studie heb ik een bijdrage geleverd aan het onderzoek naar het Huizen-materiaal door de samenhang te onderzoeken tussen de logica in hun sjabbatsdisputaties en de redactie van die disputen in Misjna en Tosefta. ${ }^{19}$ Uit dit onderzoek blijkt, dat de Sjammaieten verwantschap tonen met de oudere, praktisch gesproken striktere, sjabbatshalacha. $\mathrm{Zij}$ beoordelen een situatie of handeling op grond van de waarneembare stand van zaken. Bet Hillel daarentegen kent aan de menselijke intentie het vermogen toe, situaties en handelingen te kwalificeren. ${ }^{20}$ Haar logica, die meer rekening houdt met het bewustzijn van de mens, leidt tot een soepeler en rationelere halacha. Beide benaderingen blijken te correleren met een verschillende perceptie en een uiteenlopende waardering van de sjabbat. De Sjammaieten zien de sjabbat als een bijna

hij schroomt ook niet te wijzen op hun negatieve rol in politieke perikelen. Zelfs hun aandeel in de aanloop naar de oorlog van 67 verzwijgt hij niet. Dat maakt anderzijds zijn positieve typeringen van de Farizeeën, met hun kennis van de wet en als dominante partij met de meeste invloed bij het volk, betrouwbaarder. Zie ook de bespreking in Stemberger, Pharisäer, pp. 91-114.

18 4QMMT (Miqsat Ma' ase Tora) onderstreept het bestaan van polemieken over wetskwesties tussen de verschillende groeperingen, los van de vraag of het een echte brief is of een leerstuk in briefvorm. Enkele in 4QMMT afgewezen posities stemmen overeen met Farizeese standpunten in discussies met de Sadduceeën, zoals overgeleverd in de rabbijnse literatuur: de status van een gereinigde persoon na zonsondergang (M. Para 3:7) en de reinheid van een stroom vloeistof (M. Jadajiem 4:7). M. Machsjirien 5:9 bevat verder een glos van Bet Sjammai op de Farizeese positie in laatstgenoemde discussie. Over de identificatie van 4QMMT als Sadduceese halacha: Y. Susman, 'Research in the History of Halakhah and the Scrolls of the Judean Desert', Tarbiz 49 (1990) pp. 28-30 (Hebr.). Een datering van 4QMMT in de tweede eeuw v.g.j. en de bevestiging voor Josephus' driedeling van het Jodendom in die periode wordt beargumenteerd in D. Schwartz, 'MMT, Josephus and the Pharisees', in: J. Kampen/M.J. Bernstein (eds.), Reading 4QMMT. New Perspectives on Qumran Law and History, Atlanta 1996, pp. 67-80. Dit heeft vanzelfsprekende gevolgen voor het gebruik van rabbijnse bronnen bij de bestudering van de Tweede Tempel periode. J.M. Baumgarten concludeert, op basis van zijn belangrijke detailstudies naar de relatie tussen de reinheidshalacha van de Huizen en Qumran: 'A more serious obstacle to the proper utilization of Rabbinic halakhah for Second Temple history lies in the assumption that texts edited in a later period are of little value for illuminating phenomena of an earlier age', in: 'Recent Qumran Discoveries and Halakhah', in S. Talmon (ed.), Jewish Civilization in the Hellenistic-Roman Period. JSPSS 10, Sheffield 1991, p. 153. De onmogelijkheid daarvan wordt betoogd door J. Neusner, zie o.m. diens 'The Use of the Later Rabbinic Evidence for the Study of First Century Pharisaism', in: W.S. Green (Ed.), Approaches to Ancient Judaism 1, Chico 1978, pp. 43-63.

${ }^{19}$ Mijn dissertatie zal voor een deel aan deze problematiek zijn gewijd.

${ }^{20}$ Zie met name M. Sjabbat 1,5-10 et parr. 
goddelijke werkelijkheid waarin de mens binnentreedt. Daarin toont ze verwantschap met Qumran en Jubileeën, waar de sjabbat deel uitmaakt van de kosmische scheppingsorde. De Sjammaieten kennen de sjabbat dienovereenkomstig een heiligheid toe die vergelijkbaar is met de Tempel. Bovendien heeft de sjabbat in het dagelijkse leven een vrijwel absolute prioriteit. ${ }^{21} \mathrm{De}$ Hillelieten relativeren de sjabbat eerder ten gunste van andere geboden en benaderen haar met een accent op de menselijke maat. ${ }^{22}$ Volgens de rabbijnse traditie (B. Eroevien 13b) bepaalde de Hillelitische visie de halacha, maar feitelijk bleef ook de Sjammaïtische benadering van de sjabbat invloedrijk. ${ }^{23}$

Het bestaan van ruim 250 Huisdisputen roept de vraag op naar de relatie met de wetsdisputen in het Nieuwe Testament. De dispuutvorm is, tot op zekere hoogte, een sociaal-religieuze conventie. Disputen openbaren meningsverschillen en de daarmee correlerende sociale spanningen, maar impliceren niet noodzakelijkerwijze conflictueuze verhoudingen. In de synoptici hebben we inderdaad naast polemisch getinte debatten ook wetsgesprekken die impliciet of expliciet getuigen van overeenstemming tussen Jezus en zijn gesprekspartners. ${ }^{24}$ De dispuutvorm fungeert, tot op zekere hoogte, als het publieke kader waarin de Joods-wettelijke traditie zich ontwikkelt en waaraan een zekere felheid eigen is.

De rabbijnse literatuur roemt zelfs, ondanks de vele meningsverschillen, de goede betrekkingen tussen de twee Scholen. ${ }^{25}$ Toch is dit historisch gesproken slechts een kant van de medaille en het is zelfs de vraag, of deze tekst niet een latere, positieve inkleuring is. De bronnen reppen tevens van een 'coupe', waarbij de Sjammaieten '18 decreten' verordenden tegen de wil van de Hillelieten:

${ }^{21}$ Mechilta de-R. Isjmael, Jitro 6 (20,8) (ed. Horowitz/Rabin, p.229); Misjnat de-Rabbi Eliezer 20 (p. 364); Mechilta de-R. Sjimon ben Jochai, Jitro 20,8 (ed. Epstein/Melamed, p. 148); B. Beitsa 16a; Jalkoet Sjimoni 11, 797; Midrasj ha-Gadol Ex 20,8.

${ }^{22}$ B. Beitsa 16a, onder aanhaling van Ps 68,20 . Paulus blijkt verwant aan de Hillelitische benadering van de sjabbat waar hij in Rom 14,5-6 deze Psalmtekst parafraseert.

${ }^{23}$ Dat de Hillelitische dominantie in werkelijkheid de uitkomst was van een langdurig proces in de generaties van Yavne en Oesja blijkt uit S. Safrai,'The Decision according to the School of Hillel in Yavne', Proceedings of the World Congress of Jewish Studies 7,3 (1981) pp. $21-44$ (Hebr.). Safrai wijst op voorbeelden van Sjammaitische halacha in latere generaties. Sjammaitische invloed is echter ook zichtbaar in de redactie van de Huisdisputen in Misjna en Tosefta: zie mijn 'Impurity between Intention and Deed: Purity Disputes in First Century Judaism and in the New Testament', in: M. Poorthuis/J. Schwartz (eds.), Purity and Holiness. The Heritage of Leviticus. Jewish and Christian Perspective Series Vol. 1l, Leiden 2000, pp. 129-147 (m.n. pp. 135-141).

${ }^{24}$ Vergelijk Marcus 12, 28-34.

${ }^{25}$ M. Jevamot 1:4; P. Jevamot 1:2 (6); B. Jevamot 9a, 13a-b, 14a-b, 15a-b, 16a en 27a. 
Deze zijn uit de halachot die ze zeiden in de bovenkamer van Chananja ben Chizkia ben Gorion, toen ze opgingen om hem te bezoeken, en zij telden en zij (=Bet Sjammai) waren de meerdere over Bet Hillel. Achttien kwesties verordonneerden ze die dag. M. Sjabbat 1:4 (T. Sjabbat 1:16; P. Sjabbat1,3c; B. Sjabbat 17a en 153a)

Getuige de berichten in de Jeruzalemse Talmoed gebruikten de Sjammaieten geweld en zouden er doden zijn gevallen. Dat gegeven dienen we in samenhang te zien met de zich verscherpende politieke tegenstellingen aan de vooravond van 66, zoals Heinrich Graetz al betoogde. De Sjammaieten zouden meer op de hand zijn geweest van de zelotische partij. ${ }^{26}$ Met de uitgevaardigde maatregelen beoogden zij relaties met niet-Joden te beperken. ${ }^{27}$ Interessant is het in de oudste lijsten vermelde verbod op 'hun gaven' (מתנותן), waarmee waarschijnlijk (ook) offergaven worden bedoeld. Dit wordt bevestigd door een bericht bij Josephus, dat het beëindigen van niet-Joodse offergaven aan de Tempel een casus belli schiep. ${ }^{28}$

Het is niet zeker naar welke halachot 'deze zijn' uit de zojuist geciteerde Misjna verwijst, maar zeker is wel dat sjabbatskwesties deel uitmaakten van dit gebeuren. Dat is niet verwonderlijk: de sjabbat markeert al sinds bijbelse tijden Joden ten opzichte van een niet-Joodse omgeving. Dat werpt licht op de gedocumenteerde spanningen rond de sjabbat in de synoptische evangeliën. Het is voorstelbaar, dat de aanscherping van sjabbatswetten aan de vooravond van 66 reacties opriep in de Joods-christelijke gemeenschappen waar immers niet-Joden in toenemende mate deel van gingen uitmaken. Overgeleverde debatten tussen Jezus en zijn tijdgenoten kregen in dit licht een nieuwe, toegespitste betekenis. ${ }^{29}$

${ }^{26}$ H. Graetz, Geschichte der Juden. Von den ältesten Zeiten bis auf die Gegenwart, Band 3/2. Fünfte und verbesserte und vermehrte Auflage, Leipzig 1906 (herdruk Darmstadt 1998) pp. 809-813; I. Ben Shalom, The School of Shammai and the Zealots' Struggle Against Rome, Jerusalem 1993 (Dissertation, Hebr.).

${ }^{27}$ Zie de uitgebreide analyse in A. Goldberg, Commentary to the Mishnah Shabbat, Jerusalem 1976, pp. 15-22 (Hebr.).

${ }^{28}$ Josephus, $B J, 2,408$ vermeldt dat een priester, een zekere Eleazar zoon van Ananias, de

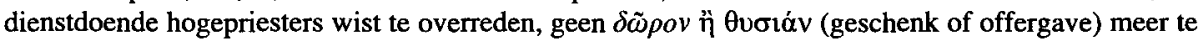
aanvaarden van niet-Joden. Dat betekende ook het stoppen met de voor de keizer bestemde offers.

${ }^{29} \mathrm{Bij}$ Mattheuis staat de eindredactie duidelijk in het teken van de toenadering tot de heidenen en het zich afzetten tegen de Joodse Umwelt: Luz, Matthäus 1/1, pp. 66-70; Tomson, 'Als dit uit de hemel is..', p. 235 . Voor de invloed van de 18 decreten op overlevering en redactie van Huisdisputen over de sjabbat, verwijs ik naar mijn dissertatie. 


\section{Werkvertaling en synoptische vergelijking Mt 12,9-14}

We presenteren de werkvertaling in de concentrische structuur van de perikoop, zoals voorgesteld door Luz (Mattheüs, pp. 236-237):

9. A) En nadat hij vandaar was weggegaan kwam hij in hun synagoge

10. B) En zie, een mens met een verstijfde hand.

C) En ze legden hem een vraag voor, zeggend, 'is het toegestaan te genezen op sjabbat?', opdat ze hem zouden aanklagen.

11. D)

Maar hij zei tot hen:

'wie van jullie is een mens, die één schaap heeft en wanneer dat valt, op sjabbat, in een put, zal hij het dan niet vastpakken en oprichten?

12.

Hoeveel meer nu is een mens dan een schaap?

C') Dus dan is het toegestaan op sjabbat goed te doen.'

13. B') Toen zei hij tot de mens:

'strek je hand uit.'

En hij strekte hem uit en deze werd wederom gezond als de andere.

14. A') De Farizeeën echter gingen naar buiten en hielden beraad, hoe ze hem zouden ombrengen.

De commentaren bieden geen bevredigende duiding van de relatie tussen Mattheüs en de parallelversies in Mc 3,1-6 en Lc 6,6-11. Mattheüs zou de voorliggende Marcaanse tekst - of een protoversie daarvan, die echter niet veel kan afwijken van Marcus $-^{30}$ sterk hebben bewerkt en samengebald. ${ }^{31}$ Maar deze hypothese verklaart onvoldoende, dat de versie van Mattheüs een geheel andere interpretatie van het dispuut biedt. Vijf obervaties onderstrepen de eigen aard van Mattheüs in verhouding tot $\mathrm{Mc} / \mathrm{Lc}$ :

${ }^{30}$ Aldus Back, Sabbath Commandment, p. 112; terughoudender Doering, Schabbat, p. 443.

${ }^{31}$ Mattheüs 'stilistisch überarbeitet und strafft' genezingsverhaal in Marcus 3,1-6, aldus Luz, Matthäüs, p.237. Doering, Schabbat, p. 457 onderscheidt drie veranderingen van Mattheüs in vergelijking met Marcus: 1. Mt formuleert verwachting van tegenstanders als directe vraag. Dat voegt vormtypisch element toe. 2 . Invoeging argument schaap: halachische analogie. 3. Dubbele retorische vraag in Mc 3,4 vormt Mt om tot een conclusie uit de analogie. Enkele verschillen zijn typisch voor Marcus, zoals het gebruik van $\pi \dot{\alpha} \lambda \iota v$ en $\varepsilon \dot{\theta} \theta \dot{\varepsilon} \omega \zeta$, evenals het gehele vers 6 . 
1. Vergelijken we de opbouw met Marcus/Lucas, dan blijkt dat Mattheüs dispuut (d) en genezing ( $g$ ) scheidt, waar Marcus en Lucas beide juist met elkaar vervlechten:

1) Intrede synagoge.

2) Man met verstijfde hand;

3) (d) Directe vraag van omstanders;

4) (d) Spreuk over 'schaap in put' (par. Lucas 14,5);

5) (d) Overgang en antwoord op vraag omstanders;

6) (g) Genezing man;

7) Beraad Farizeeërs.

Marcus/Lucas:

1) Intrede synagoge ${ }^{32}$;

2) Man met verstijfde hand ${ }^{33}$;

3) (d) Indirecte vraag omstanders ${ }^{34}$;

4) (g) Genezing man bij Lucas en in midden plaatsen van man bij Marcus ${ }^{35}$;

5) (d) Antwoord op vraag omstanders in vorm van tegenvraag;

6) (g) Genezing man bij Marcus.

7) Beraad Farizeeërs met Herodianen (zo Marcus), verbijstering van anderen en vraag 'wat met hem te doen' (zo Lucas).

2. De directe vraag in Mattheüs voegt een 'vormtypisch element' toe in vergelijking met Marcus/Lucas en versterkt zo het karakter van een dispuut. ${ }^{36} \mathrm{De}$ retorische tegenvraag van Jezus in Marcus 3,4 (par. Lc 6,9) verschijnt als positieve conclusie in Mattheüs 12,11 en is bovendien beduidend korter geformuleerd. Deze twee gegevens onderstrepen de eigenheid van het wetsdispuut bij Mattheüs en kwalificeren het bovendien als een neutraal gesprek over genezen op sjabbat. Het is, tenslotte, niet eenvoudig om deze korte en neutralere versie af te leiden uit de langere, retorische verises van Marcus en Lucas.

3. De toornige reactie van Jezus op de omstanders en het rondkijken (Mc 3,5/ Lc 6,10) ontbreken beiden in Mattheüs. Mattheüs ontbeert hier de voor Marcus/ Lucas zo typerende scherpte, ${ }^{37}$ die hem op andere plaatsen toch niet vreemd is.

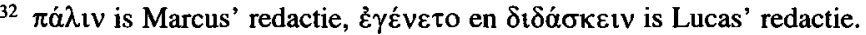

${ }^{33}$ Lucas voegt toe: $\delta \varepsilon \xi$ tà, zo ook volgens twee kleinere tekstgetuigen van Mt (sy ${ }^{\text {s.c }}$ ).

${ }^{34}$ Lucas expliciteert: schriftgeleerden en Farizeeën.

${ }^{35}$ Lucas verhaalt de genezing uitgebreider dan Marcus en Marcus uitgebreider dan Mattheüs.

${ }^{36}$ Doering, Schabbat, p. 457.

${ }^{37}$ Luz, Matthäus, p. 238.
} 
4. De Marcaanse alliantie van Herodianen en Farizeeën, historisch gezien uiterst merkwaardig, ontbreekt bij Mattheüs en bij Lucas. Lucas vermeldt in plaats daarvan 'Schriftgeleerden' en lijkt hier Marcus te corrigeren. Mattheüs doet dat echter niet.

5. De verschillen tussen Mattheüs en Marcus zijn niet terug te voeren op gedeelde Mattheüs-Lucas stof. Lucas volgt de tekst van Marcus, corrigeert (Herodianen) en vult aan met eigen elementen. Opvallend is tenslotte het afwijkende slot bij Lucas. ${ }^{38}$ Zelfs de voornaamste overeenkomst tussen Lucas en Mattheüs, het logion over de put, is bij beiden verschillend in vorm, plaats en functie. Lucas plaatst dit logion in een andere sjabbatsperikoop, de genezing van de waterzuchtige (Lc 14,1-6) en houdt zo het Marcaanse verhaalverband intact.

Formgeschichtliche observaties wijzen eveneens op de eigenheid van Mattheüs. De genezing bij Mattheüs is secundair ten opzichte van de controverse en markeert de feitelijke bezegeling van een eerder getrokken conclusie. Bij Marcus en Lucas daarentegen maken zowel de retorische vraag van Jezus als de genezing deel uit van de reactie van Jezus. De formgeschichtliche klassificatie spreekt voor Marcus en Lucas van een 'Mischform' van een genezingsverhaal en een dispuut. Mattheüs kent de eenduidiger vorm van het 'Streitgespräch'. ${ }^{39}$ Mattheüs presenteert een dispuut, gecentreerd rond de positief gestelde vraag of het geoorloofd is goed te doen op de sjabbat. Dit debat staat in een redactioneel raamwerk van oplopende spanningen tussen Jezus en de Farizeeën, maar ze ontleent daaraan niet haar primaire betekenis!

We concluderen dat de Mattheaanse overlevering in haar eigen structuur gelezen dient te worden zonder Mattheüs af te leiden van Marcus. ${ }^{40}$ Lucas

${ }^{38} \mathrm{Bij}$ hem ontbreekt de scherpe, vijandige reactie van de Farizeeën in de vorm van hun $\sigma v \mu \beta o v ́ \lambda$ iov. De Lucaanse omstanders zijn veeleer 'verbijsterd' en weten niet 'wat ze met hem moesten doen'. David Flusser/Malcolm Lowe, 'Evidence corroborating a modified proto-Matthean synoptic Theory', NTS 29/1 (1983) pp. 25-47 betogen dat Lucas hier, in vergelijking met Mattheüs, een authentieke overlevering bewaart.

${ }^{39}$ Luz wijst op de concentrische structuur die de genezing van de man naar het einde verplaatst en het dispuut in het centrum. 'Dadurch wird unsere Geschichte der Gattung nach eindeutig zum Streitgespräch.' Luz, Matthäus, p. 237, vgl. Doering, Schabbat, p. 445.

${ }^{40}$ Flusser/ Lowe, 'Evidence', pp. 30-32 betogen dat Mattheüs ook de oorspronkelijke versie biedt van het dispuut. Het is echter onnodig onze werkhypothese te koppelen aan hun voorstel inzake de synoptische kwestie. Het enige dat we hier stellen is, dat de versie van Mattheüs qua opbouw en 
bouwt voort op Marcus, kent het logion van het schaap maar plaatst dit in een ander genezingsverhaal. De plaatsing van het logion in een maaltijdcontext verraadt typisch Lucaanse interesse. Het bij Mattheüs aanwezige probleem, de gelijkstelling 'goed doen' en 'genezen', kent Lucas niet. Met de vermelding van een 'os of zoon' in de put vergelijkt hij het genezen van een mens met het redden van een dier of een mens uit de put. Precies wat je zou verwachten. Duidelijk is dat alle versies wijzen op een overlevering die uit twee elementen bestaat: het genezen op sjabbat in een synagoge en de disputatie of genezen op sjabbat geoorloofd is. ${ }^{41}$ We kunnen de oorspronkelijke overlevering(en) niet reconstrueren, noch nagaan welke versie van het dispuut de meest originele is. Het is zeker denkbaar dat meerdere historische situaties zijn verdicht in een samengestelde controverse..$^{42}$ We kunnen wel aannemen - mede op grond van de sjabbatdisputen tussen de Huizen - dat bij de oorspronkelijke overlevering(en) de controversiële sfeer behoort die onze disputen omgeeft, zij het zonder de toegespitste vijandigheid. ${ }^{43}$

\section{Redactiekritische lezing van Mt 12,9-14}

De woorden Kaì $\mu \varepsilon \tau \alpha \beta \grave{a ̀ s ~ \varepsilon ̇ \kappa \varepsilon i ̃ ~} \theta \varepsilon v$, 'en nadat hij vandaar was weggegaan', verbinden onze passage met het voorafgaande dispuut over het plukken van de aren (Luz 1990). De scène verplaatst zich van het veld naar een afgebakende ruimte, 'hun synagoge'. ${ }^{44}$ Deze beweging neemt de lezer mee naar het

qua inhoud een andere interpretatie biedt van het sjabbatsdispuut. Of deze interpretatie ook weet had van een van Marcus afwijkende versie van het dispuut is mogelijk, maar dat moet hier in het midden blijven.

41 Volgens Doering, Schabbat wijst de 'Mischform' van een genezingsverhaal en een dispuut op een formele, literaire verwerking van een, zoals hij stelt: 'historische 'Sachverhalt' dass Jesus am Schabbat geheilt hat und eben dies Auseinandersetzungen hervorrief.' (p. 445)

42 Doering's argument om onderscheid te maken tussen het tekstuele relaas en de historische werkelijkheid is dat een 'Form' een 'soziologische Tatsache' is: ' $(.$.$) die Überlieferung bildet nicht$ einfach dat Ereignis ab, sondern bringt es unter überindividuellen formgegebenen Gesichtspunkten zur Sprache.' (Schabbat, p. 445) Dat zien we ook in de rabbijnse 'ma'aseh' tradities, vermeende biografische of historische anecdotes met een specifieke, vaak halachische pointe.

${ }^{43}$ We hoeven inderdaad geen toevlucht te nemen tot de hypothese dat hier slechts sprake zou zijn van conflicten in de gemeentesituatie ('Gemeindetheologie'). Wel wijken we af van de conclusie in Doering, Schabbat, p. 445, die alleen een 'Überlieferungsinteresse' van de latere gemeente postuleert. Hij onderschat de invloed vanuit de latere situatie - we wezen op de toenemende spanningen met niet-Joden in 66 - op de verscherpende redactie van de overleveringen.

${ }^{44} \alpha u ̛ \tilde{\omega} v$ is Mattheaanse redactie en wijst volgens Luz, Matthäus, p. 238 op een niet-Joodse eindredactie. Saldarini, Matthew's Community, pp. 66-67 meent dat Mattheüs hiermee slechts die gemeenschappen bedoelt die vijandig staan tegenover Jezus of de Mattheaanse gemeente. 
midden van de op sjabbat verzamelde gemeenschap. Een man is daar ter

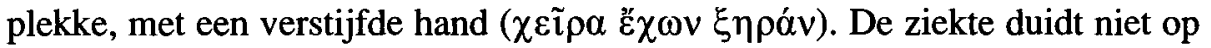
levensgevaar. Maar de 'verstijfde hand', een verder niet verklaarde aandoening, maakt ambachtelijk werk en boeren zo goed als onmogelijk. ${ }^{45}$ Blijkbaar is zijn aanwezigheid alleen al voldoende voor de omstanders om een directe vraag te stellen aan Jezus: is het geoorloofd te genezen op sjabbat? ${ }^{46} \mathrm{De}$ betrokkene zelf spreekt niet en vraagt niets. Daarmee richt de 'verteller' alle aandacht op Jezus en diens verhouding tot de sjabbat. Die concentratie is versterkt door een tweede verschuiving sinds de voorafgaande perikoop: was daar het gedrag van de leerlingen aanleiding tot een dispuut, hier wordt Jezus zelf bevraagd. In die zin is er sprake van een climactische opbouw in 12,1-14, eindigend met het beraad van de Farizeeën.

Ondanks dit redactioneel-narratieve kader met haar oplopende spanning tussen Jezus en omstanders (waaronder Farizeeën) hanteert Mattheüs de neutrale, technische term '̌ $\xi \varepsilon \sigma \tau \imath \nu$, 'toegestaan'. Deze term is synoniem met het in de rabbijns-halachische bronnen gebruikte מותר. ${ }^{47}$ We bevinden ons met deze terminologie in de sfeer van een discours over de Joodse wet, in casu de vraag naar de status van genezen op sjabbat. In dat licht is het opvallend, dat aan het begin van het discours nog geen sprake is van gemarkeerde vraagstellers. Pas op het einde blijken er Farizeeën te zijn, die bovendien beraad houden hoe ze hem zullen ombrengen. Deze plotse, expliciete vijandigheid aan het einde van de perikoop wijst op een redactionele aanscherping van reëel bestaande spanningen tussen Jezus en zijn gesprekspartners, waaronder mogelijk Farizeeën, over de sjabbat. ${ }^{48}$ Dat is eveneens het geval bij het in alle drie versies te vinden motief van het 'aanklagen' (Mt 12,10/Mc 3,3/Lc 6,7). Dit woord legt een verband tussen het dispuut en de veroordeling van Jezus. ${ }^{49}$ Bestaande

${ }^{45}$ De verklaringen variëren van atrofie (vandaar de gangbare vertaling 'verdorde' hand) via 'zenuwenverdroging' (Albertus Magnus, verwijzend naar de metselaar in het evangelie van de Hebreeën) tot psychologische verklaringen (hysterisch syndroom); zie Luz, Matthäus, p. 238, n. 12. Luz oppert dat $\xi \eta \rho o ́ \varsigma$ verwijst naar een onbewegelijke hand, vandaar ons voorstel 'verstijfde hand'.

46 żं $\varepsilon \rho \omega ́ \tau \alpha \omega$ is een 'Meidevokabel' in Mt, volgens Luz doorgaans vijandelijk gebruikt: Matthäus, p. 237, n. 6. Het woordenboek van Liddell-Scott (Oxford, 1968, repr. 10th.ed.) noemt naast 'consult, inquire': iets ter beslissing voorleggen (bijv. in het Romeinse recht). Dwingt het narratieve schema van toenemende spanning tussen Jezus en de Farizeeën/wetgeleerden tot de vertaling 'aanklagen'?

${ }^{47}$ Over de technische betekenis van $\ddot{\xi} \xi \varepsilon \sigma \tau \imath v$ : Doering, Schabbat, p. 450 n. 297.

48 Dezelfde redactionele toevoeging is te vinden in Mt 21,45.

49 Doering, Schabbat, p. 443, over Marcus 3,6. Tegen de aanname van louter redactie spreekt, dat Farizeeën volgens Marcus en Lucas geen rol spelen bij de arrestatie en terechtstelling van Jezus! Ook Mattheüs vermeldt ze niet, op twee curieuze plaatsen na $(27,62$ en 28,11$)$. Typisch voor 
meningsverschillen en spanningen tussen Jezus en (sommige) Farizeeën of 'omstanders' kregen een geladen betekenis in het licht van Jezus' terechtstelling en de vraag hoe dit zo had kunnen komen. Een tweede factor in deze redactionele aanscherping kunnen de eerder vermelde Sjammaïtische verhardingen van sjabbatswetten aan de vooravond van 67 zijn. ${ }^{50}$ Wanneer we aannemen, dat de Mattheaanse gemeente concurreerde met omringende Joodse gemeenschappen, is dat niet onmogelijk. ${ }^{51}$

Mattheüs laat nu, afwijkend van Marcus en Lucas, het logion volgen over het schaap in de put. Dat Mattheüs $\pi \rho o ́ \beta \alpha \tau o v$ (schaap) leest en Lucas viòs ßoũ s (zoon of rund) is verklaard uit een woordspel in het Aramees met de בירא :א en ר ר ב ב ב באירא (bron of put), בעא (vee). De dubbele vermelding van 'zoon of rund' bij Lucas is waarschijnlijk secundair. ${ }^{52}$ In beide versies van het logion hebben we te maken met een halachische analogie. ${ }^{53}$ Van belang is de functie van deze analogie binnen de vraag- en antwoordstructuur van Mattheüs. Mattheüs accentueert dat er sprake is van één schaap: $\pi \rho o ́ \beta \alpha \tau o v ~ \varepsilon ̋ v$. Daarmee roept hij de Nathanfabel in herinnering: de arme man die slechts één schaapje had (2 Sam 12,3) dat hem werd ontnomen. Luz concludeert dat deze analogie de sfeer oproept van 'ländlich-ärmlichen

\footnotetext{
Mattheüs is de ambivalente waardering voor Farizeeërs. Naast scherpe polemieken tegen de Farizeeën (Mt 23) bevestigt Jezus immers hun religieuze leiderschap (23, 2.23). Saldarini, Matthew's Community, pp. 133-134 wijst ook bij onze perikoop op het dubbelzinnige karakter: een debat waarin de argumenten van de tegenstanders impliciet gewaardeerd worden, maar tegelijk een polemiek. Ofschoon Jezus zeker niet als 'sjabbatsbreker' werd veroordeeld (Doering, Schabbat, p. 443, wijst er terecht op, dat de lijdensverhalen niet refereren aan de sjabbat!), mogen we wel reële meningsverschillen met de daarbij behorende spanningen rond de aanspraak op religieus leiderschap vooronderstellen.

${ }^{50}$ De Farizeeën van Mattheüs zouden in dat geval staan voor de strikte, Sjammaitische factie.

51 Dat wordt betoogd in Saldarini, Matthew's Community.

52 Volgens sommigen is de spreuk uit 'Q', maar Back, Sabbath Commandment, p. 133 bestrijdt dat: 'two different versions of the same saying.' Mogelijk uit $Q$, maar 'unlikely' vanwege 'slight agreement in wording'. Hij wordt gevolgd door Doering, Schabbat. De hypothese van een Aramees woordspel gaat terug op M. Black, An Aramaic Approach to the Gospels. 3d. ed., Oxford 1967, p. 135. Zie Doering, Schabbat, pp. 458-459. Back, Sabbath Commandment, p. 136 gaat uit van de ontwikkeling van een uitgebreidere $(\mathrm{Lc})$ naar een kortere $(\mathrm{Mt})$ versie van het woordspel. Doering daarentegen pleit, mijns inziens overtuigend, voor de ontwikkeling van kort (Mt) naar uitgebreid (Lc). De klankverwantschap tussen בירא en (vee) בעירא (put) is sterker en de associatie kan worden verklaard uit het wegvallen van de gutturaal in het westelijke Aramees. Zoon, ברא, staat kortom aan het einde van de ontwikkeling, niet aan het begin. Overtuigend lijkt mij vooral zijn argument dat Mt de zoon niet eerst weghaalt om die in zijn conclusie weer in te voegen!

53 Doering, Schabbat, p. 460 in navolging van Luz en contra Back, Sabbath Commandment, p. 140.
} 
Verhältnisse Palestinas', de situatie van een arme boer of dagloner. ${ }^{54}$ De halachische analogie wordt afgesloten met een compact geformuleerde a fortiori

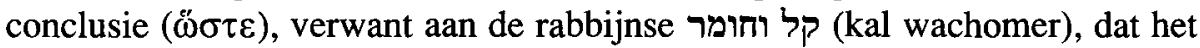
is toegestaan goed te doen op de sjabbat. ${ }^{55}$

De conclusie van Jezus wijkt af van die vraag of het is toegestaan te 'genezen op sjabbat'. Hoe volgt uit het feit dat je een schaap mag redden op sjabbat dat je goed mag doen op sjabbat? De geboden verklaringen gaan uit van de analogie tussen (dierlijk) leed en (menselijk) leed. Schematisch gezien loopt het antwoord van Jezus dan als volgt:

Dier in nood

Dier redt men

Mens in nood

Mens redt men

De gelijke noemer is dat zowel dier als mens in nood verkeren. Maar deze logica wringt met het feit, dat de betrokken persoon niet in onmiddellijk levensgevaar verkeert. Evenmin correleert het redden van het dier met de con-

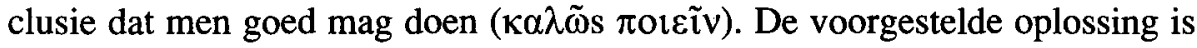
dan ook geenszins bevredigend.

We constateerden al dat Lucas dit probleem niet heeft. Zijn versie benadrukt voor zowel mens als dier het onmiddellijke $(14,5)$ karakter van redding. Lucas vergelijkt het redden van 'zoon of os' met het genezen van de zieke. ${ }^{56}$ In beide Lucaanse sjabbatsdisputen is de vraag die naar de noodzaak om onverwijld een zieke mens te helpen, ook op sjabbat. Aan welke logica refereert Mattheüs?

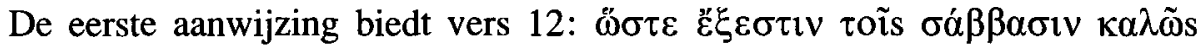
$\pi$ oteiv. We stelden al vast dat dit antwoord de vraag, of het is toegestaan te genezen in een ander licht plaatst. Dat Jezus met zijn antwoord het verwachtingspatroon doorbreekt van degene die hem een kwestie voorlegt, zien we ook in de perikoop over het betalen van belastingen aan de keizer (Mc 12,1317/ Mt 22,15-22/ Lc 20,20-26) en in de vraag van Jezus in de parabel van de barmhartige Samaritaan (Lucas 10,36). Dat betekent niet dat Jezus de vraag ridiculiseert, wel dat hij de vraag in een ander perspectief plaatst als waarin de

${ }^{54}$ Luz, Matthäus, p. 239: 'Immerhin könnte Jesus eine Bauernhalacha (...) aufgegriffen haben.' Doering, Schabbat, p. 461, meent dat hier veeleer een Joods-christelijke argumentatie ligt. Deze verlegenheidsoplossing verschuift het probleem alleen maar!

${ }^{55}$ Doering, Schabbat, p. 461: 'Matthäus ist darin von seiner jüdischen Umwelt geprägt, dass er wie auch die Tannaiten - Schabbatverdrängungen durch Schlüsse a fortiori zu begründen versucht.'

${ }^{56}$ In Lucas geneest Jezus de waterzuchtige eerst voordat hij de omstanders beantwoordt, daarbij

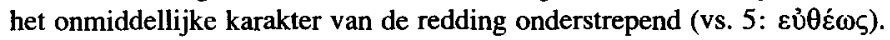


vragensteller haar opwierp. Genezen op sjabbat plaatst hij zo in het kader van 'goed doen' op sjabbat.

Dat kader 'goed doen' staat in een typisch Mattheaanse samenhang van 'goede werken'. Jezus wijdt hierover uit in het oordeel van de Mensenzoon (Mt 25, 31-46), waar hij wijst op het geven van eten, het laven, het kleden, het verlenen van gastvrijheid en het bezoeken van zieken en gevangenen. Eerder al $(12,6)$ haalt hij in het debat over het aren plukken op sjabbat Hosea 6, 6 aan: 'Erbarmen wil ik en niet offer'. ${ }^{57}$ De commentaren onderstrepen terecht het belang van dit vers in het geheel van de sjabbatsdisputen. ${ }^{58}$ Het is in dit verband van belang, dat de rabbijnse literatuur Hos 6,6 leest als verwijzend naar het doen van 'goede werken' ${ }^{59}$ Mattheüs werkt eveneens met die connotatie. Hij plaatst de sjabbat vanaf 12,6 onder de prioriteit van 'barmhartigheid', als 'goed doen', te weten 'goede werken'. ${ }^{60}$ Helaas trekken de meeste commentaren hieruit de aan het begin van onze studie vermelde conclusie, dat deze prioriteitstelling de sjabbatswet doorbreekt en dat Jezus de sjabbatsobservantie onder de kritiek van het beginsel van de liefde stelt.

Precies op dit punt wreekt zich helaas een onbereflecteerd uitgangspunt van exegetisch onderzoek. Dat is, dat de sjabbat voor christelijke exegeten geen vanzelfsprekende realiteit vormt. ${ }^{61}$ Evenmin neemt men waar, dat ogenschijnlijk technische, halachische discussies over activiteiten op sjabbat fundamenteel theologische concepten kunnen belichamen, zij het in een taal die zeer impliciet is. In dit geval gaat het om twee positieve waarden: goede werken

${ }^{57}$ De NBG vertaalt: 'Want in erbarmen heb ik behagen en niet in slachtoffer'.

58 Jezus citeert Hos 6,6 ook in het dispuut met Farizeeën (!) over eten met zondaars en tollenaars (Mt 9,16). Zie L. Lybaek 'Matthew's Use of Hosea 6.6 in the Context of the Sabbath Controversies', in: C.M. Tucket (ed.), The Scriptures in the Gospels, Bibl. Eph. Theol. Lov. 131, Leuven 1997, pp. 491-499.

${ }^{59}$ De klassieke tekst is op naam van Rabban Jochanan ben Zakkai die zijn leerlingen na de verwoesting van de Tempel wijst op het verzoenende karakter van daden van barmhartigheid: Avot deRabbi Natan, versie a, 4 (ed. Schechter, p. 11a). Luz, Matthäus 1/1, pp. 71-72 wijst op de verwantschap tussen Rabban Jochanan ben Zakkai en Mattheüs.

${ }^{60}$ De prioriteitstelling van 'erbarmen' vinden we ook in Mt 23,23. 'Recht, barmhartigheid en trouw' kwalificeert Jezus, verwant aan rabbijnse terminologie, als 'het zwaarste van de wet'. Dat betekent niet dat het afdragen van de tienden van munt, anijs en komijn daarmee overbodig is geworden. Het afdragen van de tienden van deze kruiden wordt bevestigd in rabbijnse bronnen. Vgl. Saldarini, Matthew's Community, pp. 141 e.v.

61 Vergelijk Luz, Matthäus 1/2, pp. 236 en 233-34. De Mattheaanse gemeente heeft de sjabbat wel onderhouden, zie Mt 24,20! Volgens Lybaek 'Matthew's Use', zou Mt Hosea citeren om aan te tonen, dat in Jezus de schriftuurlijke barmhartigheid van God tot vervulling is gekomen. Dat schept een alternatief voor de verwoeste Tempel, anders dus dan bij Raban Jochanan ben Zakai. Het hoeft weinig betoog dat we met deze christocentrische exegese ver verwijderd zijn geraakt van de aanleiding voor het dispuut: de sjabbat. Die is blijkbaar van ondergeschikt belang. 
en de sjabbatsrust. Waar Jezus het onderhouden van de sjabbat 'ordent onder' het doen van goede daden, is dit geen kritiseren van sjabbat of sjabbatsobservantie, maar een prioriteitstelling in een concrete situatie. We komen op dit punt nog terug.

$\mathrm{Na}$ de verbale disputatie richt Jezus zich tot de mens met de verstijfde hand met een simpel woord: 'strek je hand uit' (vs. 13). De hand blijkt genezen, 'zoals de andere'. Eerder stelden we met Luz vast, dat voor Mattheüs de narratieve pointe van de perikoop is gelegen in zijn antwoord, niet - zoals in Marcus en Lucas - in de genezing. Op dit punt blijkt pas dat er Farizeeën waren: die gaan immers nu de synagoge uit en houden beraad 'hoe hem te doden'. ${ }^{2}$ Dat neemt niet weg dat het zeer zeker mogelijk is dat Farizeeën tot de 'omstanders' behoorden, maar die markering lijkt hier secundair. Welke de aanleiding is voor het beraad - de genezing, het antwoord van Jezus of beiden samen - blijft onduidelijk en we hebben dit vers dan ook getypeerd als redactioneel. De verzen 10c en 14 verbinden onze episode met een overkoepelende verhaalstructuur.

In dit verband is het afwijkende slot bij Lucas inderdaad belangrijk. Lucas beperkt zich tot de vaststelling, dat de omstanders vervuld waren van 'verbijstering' ( $\dot{\varepsilon} \pi \lambda \eta \sigma \theta \eta \dot{\sigma} \sigma \alpha \nu$ àvoí $\alpha \varsigma$ ) en zich afvragen 'wat ze met hem zullen gaan doen'. Bij Lucas bieden Jezus' woorden of handelingen geen aanleiding om hem te beschuldigen van het overtreden van de wet. Flusser meent, dat Lucas hier een oorspronkelijk detail heeft bewaard van onze episode. ${ }^{63}$ Dat is zeer wel mogelijk, al vooronderstelt Flusser, dat Jezus niets deed dat in strijd was met de aanvaarde halacha over het genezen op sjabbat. Dat voert ons wederom tot de vraag naar de logica van het Mattheaanse dispuut.

\section{Het dispuut in het licht van vergelijkend wethistorisch onderzoek}

Is het mogelijk die logica op het spoor te komen door de betreffende wetskwesties in de tekst te analyseren in vergelijking met andere bronnen?

De vraag van de omstanders in Mattheüs is, zoals we zagen, afwijkend van Marcus/Lucas en neutraal geformuleerd: is het toegestaan op de sjabbat te genezen? Mattheüs laat Jezus deze vraag in twee stappen beantwoorden: hij poneert de analogie van het schaap in de put en trekt vervolgens een expliciete

\footnotetext{
${ }^{62} \sigma u \mu \beta$ oú $\lambda$ ıov $\lambda \alpha \mu \beta \alpha v \varepsilon ı v$ is een latinisme (consilium capere). Zie Luz, Matthäus, p. 238.

${ }^{63}$ Flusser/Lowe, 'Evidence', pp. 30-31, verwijzend naar de eendere situatie en gebruikte bewoordingen in Handelingen 4,15-16.
} 
conclusie. Aangezien het onderzoek beide stappen als afzonderlijke kwesties beschouwt, zullen we ze eerst onderscheiden bespreken.

\section{Eerste kwestie: genezen op sjabbat}

Op Epstein gaat de door Flusser verdedigde hypothese terug, dat de synoptische Jezus geen verboden handelingen verrichtte bij zijn genezingen op sjabbat. Hij genas slechts met verbale handelingen, hetgeen was toegestaan. Epstein wijst op baraitot die het 'fluisteren over het boze oog, de slang en de schorpioen' toestaan. ${ }^{64} \mathrm{De}$ negatieve verwachting en dito reactie van de omstanders zouden op een strictere oude halacha wijzen, die ons niet meer bekend is.

Deze uitleg wordt niet door iedereen aanvaard. Critici wijzen op de late bronnen die voor deze hypothese worden aangehaald en op de problematische relatie tussen de daar besproken magische handelingen en het genezen. Bovendien zouden de vragen en reacties in de synoptici een indicatie zijn voor het problematische karakter van genezen op sjabbat. ${ }^{65}$ Flusser zou, kortom, te veel harmoniseren.

Deze kritiek acht ik steekhoudend, althans voor zover de genezing door Jezus slechts met veel moeite is te duiden vanuit voornoemde magische activiteiten. Maar we mogen hieruit niet afleiden, zoals enkele auteurs vervolgens doen, dat $d e$ halacha ten tijde van Jezus vast lag. Die conclusie valt niet af te leiden uit houding en reactie van de omstanders. ${ }^{66}$ Verder wijst Flusser er terecht op, dat de sjabbat voor Jezus een Mozaïsch gebod was. Vraag en antwoord hoeven niet uit polemische motieven verklaard te worden, aangezien de vraag naar het genezen past binnen het godsdienstige klimaat van die dagen. ${ }^{67}$

${ }^{64}$ J.N. Epstein, Introduction to Tannaitic Literature. ed. by E.Z. Melamed, Jerusalem 1957 (Hebr.), p. 281: T. Sjabbat 7[8], 23; P. Sjabbat 14,3 (14c); B. Sanhedrin 101a. Gevolgd door D. Flusser, Jesus. Een Joodse visie. Geheel herziene druk. Hilversum 2001, pp. 53-55; Sanders, Jewish Law, p. 21; Saldarini, Matthew's Community, p. 133 en Doering, Schabbat, p. 446 n. 281. Zie ook de uitstekende analyse van M. Kister, 'The Plucking on the Sabbath and Christian-Jewish Polemic', in: Immanuel 24/25 (1990) pp. 35-51, met name pp. 41-42 en n. 24.

${ }^{65}$ Back, Sabbath Commandment, pp. 47-48; Doering, Schabbat, pp. 446-447.

${ }^{66}$ Back, o.c.; Doering, o.c. Luz, Matthäus, p. 241 lijkt voorzichtiger en spreekt zich niet uit over een bestaande halacha die genezen verbiedt en wijst er op, dat volgens de omstanders het genezen niet op de sjabbat plaats had hoeven vinden. Jezus zou slechts 'überkommene Religiosität' willen doorbreken.

${ }^{67}$ Zoals Luz, Matthäus, p. 236: 'Die Gegner wissen offenbar schon, dass Jezus am Sabbat heilen wird, und fragen nur, um ihn gerichtlich anzuklagen.' Dit oordeel - gebaseerd op het narratief-redactionele aanklagen (vs. 10) - vooronderstelt historisch gesproken een centraal gezag en een vaststaande sjabbatshalacha! 
Nader bezien ontbreekt in de nabijbelse, vroeg-Joodse bronnen exacte informatie omtrent de status van medische activiteiten op sjabbat. ${ }^{68} \mathrm{We}$ hebben evenmin Huizen-materiaal of oude overleveringen uit de rabbijnse literatuur over deze kwestie. De bronnen laten wel twee lijnen zien die samenhangen met genezen.

Allereerst die van פקוח נפש, pikkuach nefesj, het redden van een leven. Dat tannaitische beginsel, dat in een zeer restrictieve variant waarschijnlijk ook bekend was in Qumran, maakt het mogelijk de wetten van de sjabbat opzij te zetten (דוחין, dochien) ter wille van levensredding. Daaronder valt volgens de tannaïem ook twijfel omtrent levensgevaar. ${ }^{69}$ De term is ontleend aan een specifieke casus, namelijk het redden van levens wanneer een huis is ingestort op Grote Verzoendag - die geldt als een sjabbat bij uitstek -. De oude halacha is, zoals gezegd, hierin zeer strikt. In Qumran is het alleen toegestaan om iemand uit een put te halen met behulp van de eigen kleding. Men verbood het gebruik van andere hulpmiddelen. De rabbijnse opvatting kiest hierin voor de mens: in geval van levensgevaar of twijfel daaromtrent worden sjabbatsrestricties opzij gezet. De latere generaties versoepelen die regel nog verder (P. Sjabbat 14:4 (14d); B. Sjabbat 109a). We dienen echter in herinnering te roepen dat in alle versies van de 'verstijfde hand' geen sprake is van levensgevaar. Dat lijkt hier dan ook niet ter discussie te staan. Slechts een niet door teksten ondersteunde hulpconstructie kan de verklaring vanuit de regel voor levensgevaar stutten. ${ }^{70}$

De tweede lijn is die van discussies uit de tweede eeuw over het bereiden en toedienen van geneesmiddelen en van medische handelingen op sjabbat. ${ }^{71}$ In

${ }^{68}$ Back, Sabbath Commandment, p. 48 stelt wel vast dat de Misjna geen melding maakt van genezen maar beroept zich niettemin op 'most authors'. Genuanceerder Doering, Schabbat, p. 448 : '(...) ergibt zich die erstaunliche Auskunft, dass keine einzige nichtchristliche Quelle aus vortannaitischer Zeit sabbatliches Heilen erwähnt.'

69 In de context van Grote Verzoendag, op naam van Mattitja b. Cheresj in M. Joma 8,6. De terminologie in M. Joma 8,7. Zie ook T. Sjabbat 9,22; 15,16-17; Mechilta Ki Tesa on Ex 31,13 (ed. Horovitz/Rabin p. 340-341); M. Sjabbat 14, 3-4; T. Sjabbat 13, 9-11; B. Joma 84b-85a. Hierover Sanders, Jewish Law, p. 13. Dat dit beginsel zou teruggaan op de beslissing van de Makkabeeën om zichzelf te verdedigen op de sjabbat (1Mace 2,49-51; 2 Macc 5,25 ff.; Josephus: Joodse Oorlog 1. 145-147; 157-160) wordt betwijfeld in H. Weiss, 'The Sabbath in the writings of Josephus', JSJ 29/4 (1998) pp. 363-390 en Doering, Schabbat, pp. 270-71. Josephus zelf waardeert een zeer strikte sjabbatstraditie waarin het breken van de sjabbatswetten in geval van gevaar geen vanzelfsprekendheid is. Ook Mattheüs lijkt te delen in deze traditie: Mt 24,20!

${ }^{70}$ Back, Sabbath Commandment, p. 112 extrapoleert daartoe het retorische karakter van de Marcaanse vraag: niet goed doen is slecht doen is doden. Dit is een voor toehoorders onhoudbare logica, aldus Doering, Schabbat, p. 451. Bij Mattheuis gaat deze verklaring niet op.

${ }^{71}$ M. Sjabbat 14,3f; 22,6; T. Sjabbat 12[13],8-14; 16[17],16.19. 
het algemeen luidt de rabbijnse visie, dat het niet is toegestaan opzettelijk genezende handelingen te verrichten op sjabbat. Wel is het toegestaan verzachtende middelen toe te dienen of manipulaties te verrichten bij wonden bijvoorbeeld om het pus vrij te laten - en indien achteraf blijkt dat dit een genezend effect had, is er geen probleem. Vorm en inhoud van rabbijnse discussies wijzen op twee zaken: men debatteert over de grens tussen direct en indirect genezen en deze kwestie raakt aan de gevoelige gezagsverhoudingen tussen de rabbijnen. Een enkel voorbeeld laat dat duidelijk zien:

(A) Men bereidt zalf voor de zieken op sjabbat.

(B) Wanneer? Indien iemand heeft gemengd op erev sjabbat.

Indien hij niet heeft gemengd op erev sjabbat, is het verboden.

Want men begint niet met mengen op erev sjabbat.

(C) $\mathrm{En}^{72}$ ze mengen geen wijn en olie op sjabbat voor de zieken.

R. Sjimon b. Eleazar zei in naam van R. Meir:

Men mengt wijn en olie op sjabbat voor de zieken.

(D) R. Sjimon ben Eleazar zei:

eens werd R. Meir ziek en wij wilden voor hem bereiden en hij liet het niet toe. Wij vroegen hem: Meester, ontken je je mening tijdens je leven?

Hij zei tot ons: ook al zei ik het zo, ik heb het nimmer gewaagd de mening van mijn collega's te doorbreken.

T. Sjabbat 12,12; zie ook P. Berachot 1,1 (3a); P. Sjabbat 14,3 (14c); B. Sjabbat 134a.

De casus onderzoekt twee kwesties in het grensvlak van genezende handelingen op sjabbat: het bereiden van zalf en het mengen van olie en wijn, een verzachtend en medicinaal mengsel voor zieken. De misjna combineert tegenstrijdige overleveringen. (A) is een anonieme halacha die het prepareren van zalven voor de zieke toestaat. Het vervolg (B) legt echter een restrictie op: slechts wanneer men op erev sjabbat mengt is het toegestaan. Deze tegenspraak met de opening wijst op een samenvoegen van tegengestelde standpunten. Of de redactie tegenstrijdige visies uniformeert, dan wel een ouder standpunt inperkt vanuit een latere ontwikkeling, valt niet na te gaan. Duidelijk is, dat er geen eenduidige halacha ten grondslag ligt aan deze misjna! Dat blijkt ook uit het vervolg. (B) verbiedt het mengen van olie en wijn op sjabbat. De mening van $R$. Meïr wijkt hier van af. R. Meïr geeft het welzijn van de zieke voorrang boven de heiligheid van de sjabbat, ofschoon hij voor zichzelf de striktere regel toepast, zoals blijkt uit (D) ${ }^{73} \mathrm{R}$. Meirs mening lijkt in

\footnotetext{
72 1: in ms. Erfurt en ms.London. Volgens deze mss hebben we dus te maken met één overlevering, ms. Vienna laat de mogelijkheid open dat we twee afzonderlijke overleveringen hebben.

${ }^{73}$ Het gaat hier bovendien niet om de voortgaande medicatie op sjabbat (T. Sjabbat 16,12 en B. Joma $84 b-85 a)$ maar het bereiden van zalf op de sjabbat.
} 
lijn te zijn met de soepele regel in (A) maar in (D) conformeert hij zich aan de striktere positie van zijn collega's, zodra het hem zelf betreft. Het relaas maakt duidelijk dat deze kwestie gevoelig lag in de gezagsverhoudingen tussen de leraren. ${ }^{74}$ Bedenken we daarbij dat hier geen levensgevaar of zelfs twijfel daarover speelt. De casus laat kortom zien dat nog in de tweede eeuw de halacha ten aanzien van het verzorgen van zieken op sjabbat niet vast lag. Voor dit moment volstaat het te concluderen, dat we geen harde gegevens hebben voor de eerste eeuw over situaties waarin geen sprake is van levensgevaar.

\section{Tweede kwestie: schaap in de put}

Jezus suggereert met zijn vraag dat het voor zijn toehoorders vanzelfsprekend is dat je een schaap helpt dat in een put of cisterne is gevallen. De casus van een schaap of stuk kleinvee dat in een put of bron terecht komt op sjabbat, geldt volgens Luz als een 'Musterfall'. De Qumranitische voorschriften staan het niet toe een dier dat in een put of cisterne (בור) is gevallen, er uit te halen. ${ }^{75}$ De tannaitische halacha (T. Sjabbat $14[15], 3$ ) staat het evenmin toe een dier dat in een cisterne of in een bron (באר) is gevallen er uit te halen. Maar men dient er wel er voor te zorgen dat het niet van honger en dorst omkomt. ${ }^{76}$ Volgens Rav (B. Sjabbat 128 b) is het zelfs toegestaan om kussens en dergelijke onder het dier te leggen zodat het uit zichzelf omhoog kan klimmen uit een waterstroom (אמת המים). ${ }^{77}$ Daarmee wordt het verbod op dragen van voorwerpen op sjabbat, dat in Qumran het redden aan stricte restricties bindt, versoepeld. Maar ook in dat geval is het actief omhoog halen van een

${ }^{74}$ R. Goldenberg, The Sabbath laws of R. Meïr. Brown Judaic Studies 6, Missoula 1978, p. 41 leest het relaas als een pleidooi voor eensgezindheid tussen de leraren. Dat is juist, maar aan dat pleidooi gaat wel een fundamenteel verschil van mening vooraf. De tekst roept de indruk op dat dit meningsverschil door de latere traditie (i.c. Sjimeon ben Eleazar) op irenische wijze is gemaskeerd. L. Ginzberg, Commentary on the Palestinian Talmud 1, New York 1971 (herdruk), pp. 84-86 plaatst de casus binnen de spanning tussen een strictere meerderheidsopinie en een liberaler minderheidsstandpunt. Daarbij geldt dat hetgeen je, anders dan je opponenten, voor anderen toestaat, je voor jezelf niet toestaat uit respect voor de meerderheidsopinie. In de samenhang van halachische kwesties met sociaal-religieuze autoriteitsaanspraken van de leraren tekent zich een parrallel af met de synoptische debatten tussen Jezus en de Farizeeën.

${ }_{75}$ CD 11, 13-14a. Parallel in 4QD(e) 6V; 4QD (f) 5 1, 8-9. Doering, Schabbat, pp. 193-195.

76 Ms Vienna leest לתוך הבור (put, cisterne); ms. Erfurt באר (bron). S. Krauss, Talmudische Archäologie 1, Leipzig 1910, p. 79 wijst er op dat deze verwisseling wel vaker voorkomt.

${ }^{77}$ Of deze derde eeuwse Babylonische leraar, die in Palestina studeerde, een oudere traditie aanhaalt of een versoepelende eigen visie leert, valt niet na te gaan. 
dier niet toegestaan. Alleen tijdens een feestdag is er sprake van die mogelijkheid, zo blijkt uit een discussie tussen R. Eliezer en R. Josjoea. ${ }^{78}$

Het is van belang vast te stellen dat ook Mattheüs niet spreekt over het uit de put halen van een schaap. Volgens zijn versie van de analogie mag je een schaap oprichten. ${ }^{79}$ Hierin is hij verwanter aan de rabbijnse logica dan Lucas, die spreekt over het uittrekken uit de put en daarmee onkunde verraadt van rabbijnse halacha ${ }^{80}$ Luz' hypothese dat we hier wellicht hebben te maken met 'kleinbäuerliche Halacha' die af zou wijken van de theoretische, restrictievere halacha, is mogelijk maar niet noodzakelijk. ${ }^{81} \mathrm{Zijn}$ vooronderstelling dat de Gallileese halacha op gespannen voet zou staan met de Farizeese is echter discutabel. ${ }^{82}$ Maar of Jezus nu verwantschap toont met de latere rabbijnse halacha dan wel teruggrijpt op een bekende en aanvaarde traditie, de relatie tussen analogie en conclusie blijft onverklaard.

\section{Genezen als 'goed doen': het voorkomen van bedelarij}

De Mattheaanse logica wordt inzichtelijk indien we ons uitgangspunt nemen in onze eerdere conclusie, dat de Mattheaanse Jezus de vraag naar genezen plaatst in het kader van goede werken op sjabbat. We wezen er op dat de geboden verklaringen uitgaan van de vergelijking tussen een dier in nood en een mens in nood. De relatie tussen eigenaar en beest is dan analoog aan die

${ }^{78}$ T. Yom Tov 3:2 (ed. Lieberman, p. 293). Dat het om een feestdag gaat blijkt uit het feit, dat men het dier er uit mag halen om het te slachten, hetgeen op een feestdag maar niet op sjabbat is toegestaan.

${ }^{79}$ Dat lijkt me, met Tomson, 'Als dit uit de hemel is...', p. 193 de juiste vertaling van $\varepsilon \hat{\gamma} \varepsilon \rho \varepsilon \tilde{\imath}$. Luz, Matthäus, p. 239, n. 15: '(...) setzt gerade voraus, dass man das Schaf aktiv herausholt (...).' Dat klopt niet met de betekenis in Liddell/Scott: awaken, rouse, stir up, raise (from dead or sickbed, met verwijzingen naar Mt 10,8; 1Cor 15,42 en Jac 5,15). Tomson maakt echter niet duidelijk, waarom Mattheüs hier, in tegenstelling tot Lucas, de 'exacte halachische uitdrukking' zou gebruiken. De rabbijnen spreken nergens van oprichten. Verwantschap tussen Mattheüs en de rabbijnse halacha blijkt hooguit uit de logica van Rav, dat je het dier helpt, zichzelf uit de benarde toestand te bevrijden.

${ }_{80}$ Aldus Tomson, o.c.

${ }^{81}$ Doering, Schabbat, p. 461, oppert dat dit argument teruggevoerd dient te worden op intern gebruik door Jodenchristenen. Dat lost het probleem niet op en staat op gespannen voet met het oordeel van de meerderheid van auteurs die het logion als authentiek waarderen (zie p. 460, n. 352).

${ }^{82}$ Luz, Matthäus, p. 238. Voorzichtiger conclusie in Doering, Schabbat, p. 460, n. 350: in een stedelijke omgeving zou Farizeese invloed sterker zijn dan op platteland. Overigens heeft S. Safrai deze hypothese bekritiseerd in 'The Jewish Cultural Nature of Galilee in the First Century', Immanuel 24/25 (1990) pp. 147-186. Eerder al wees hij op de typisch Galileese tradities van de chassidiem risjoniem, waarvan hun striktere sjabbatshalachot opvallen: 'Teachings of Pietists in Mishnaic Literature', JJS 16 (1965) pp. 15-33, met name 21 vv. Zie ook 'Chassidiem weansjei ma'ase', Zion 50 (1985) pp. 133-154, m.n. 134-138 (Hebr.). 
tussen genezer (Jezus) en zieke mens. De expliciete referentie van Mattheüs aan de Nathanfabel (één schaap, 2Sam 12,3) roept echter de sfeer op van de nood van de eigenaar die zijn ene schaap in gevaar weet. De analogie van het schaap in de put en de zieke is dan gebaseerd op het dreigende verlies van levensonderhoud: in het ene geval door het verliezen van het enige schaap, in het tweede geval door de ziekte. De gelijke noemer is dus niet (acuut of dreigend) levensgevaar maar dreigende of acute armoede. Het antwoord van Jezus dat 'goed doen' is geoorloofd, dienen we dan te begrijpen als het redden van levensonderhoud.

Zowel wetvergelijkende als tekstuele gegevens ondersteunen die uitleg. We wezen al op het Mattheaanse antwoord dat het is toegestaan goed te doen,

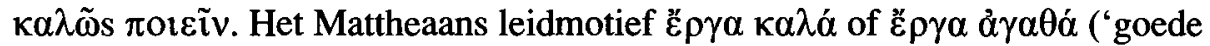
werken') is nauw verwant aan het rabbijnse concept מעשים טובים, ma'asiem toviem ('goede werken'). Dit concept omvat in eerste instantie גמילות חסד, gemillut chesed (liefdewerken), dat staat voor een wisselende coalitie van handelingen. Eigen aan handelingen van 'gemillut chesed' is dat ze niet formeel in de Tora worden voorgeschreven en betrekking hebben op de relatie tussen mens en medemens. Het concept fungeert als een theologische kwalificatie voor activiteiten op het vlak van de verhouding tussen mens en medemens en aan de rand van de bijbelse geboden. We treffen de term ook aan in teksten die de zwaarte van deze handelingen in relatie tot de geboden wegen. ${ }^{83}$ Samen met liefdadigheid (צדקה, liefdadigheid) overlapt dit concept met het bredere מעשים טובים, ma'asiem toviem (goede daden), waar het soms ook deel van uit maakt. ${ }^{84}$

Men is er echter ten onrechte van uitgegaan, dat we met 'goed doen' of 'goede daden' het terrein van de halacha verlaten ten gunste van het idee van de liefde. Er is inderdaad sprake van een zeker onderscheid tussen geboden en goede werken, soms zelfs van spanning als het gaat om de prioriteit, maar de

${ }^{83}$ Zoals in M. Pea 1,1 het geval is binnen een agadisch discours en in M.Baba Batra 9,4 binnen een halachisch discours.

${ }^{84}$ Zie Mechilta deRabbi Sjimon Ben Jochai, 18,1; M.Avot 3,11 en 6,9; Mechilta deRabbi Isjmael, Jitro 1 (ed. Horowitz/Rabin, pp. 189-190) verklaart de naamsveranderingen van Jitro, Abraham, Sara en Jozua op grond van hun 'goede werken'. Merk op dat zij niet bekend konden zijn met de geboden van Sinai. Zie H. Strack/P. Billerbeck, Kommentar zum Neuen Testament aus Talmud und Midrasch. Vierter Band. Exkurse zu einzelnen Stellen des Neuen Testaments, zweiter Teil, 4. Auflage, Munchen 1965, onder 'Die altjüdischen Liebeswerke' (pp. 559-610). Een historisch systematisch onderzoek naar dit concept is een desideratum. Voor liefdewerken in het Nieuwe Testament en hun functie in Mattheuis: Wim Weren, De broeders van de mensenzoon. Mt 25,31-46 als toegang tot de eschatologie van Mattheüs, Amsterdam 1979 (dissertatie), pp. 59-65. 
vraag naar de onderlinge relatie behoort zonder twijfel tot de sfeer van de halacha. ${ }^{85}$ Een voorbeeld is een halacha die bespreekt wat te doen wanneer een dode of een bruid voorbijkomt terwijl men met een positief gebod bezig is, in casu de studie van de Tora:

Wanneer twee leerlingen studeren en zich bezig houden met de Tora, en er gaat een bruid of een baar van een dode voorbij, dan hoeven zij hun studie niet te onderbreken wanneer er voldoende mensen aanwezig zijn in de stoeten. Maar indien niet, dan staan ze op en bejubelen en prijzen de bruid of vergezellen de dode.

Avot de Rabbi Natan versie a, 4 (ed. Schechter p. 9b)

Het vergezellen van de bruid en het begraven van de dode behoren tot de 'liefdewerken' (gemillut chesed) of 'goede werken'. De verplichting van een 'goed werk' botst hier met een ander positief gebod, te weten de studie van de Tora. Uit de bronnen blijkt, dat dergelijke discussies ook worden gevoerd over de relatie tussen de sjabbat en andere, positieve geboden. Zo debatteren de Scholen over het brengen van offers op sjabbat (M. Beitsa 2,4). Een bekende traditie verhaalt hoe Hillel de Oude het slachten van pesachlammeren op sjabbat verdedigde tegen de 'zonen van Bathyra' (P. Pesachiem 6,1). Laten we nog eens nader kijken naar de ons bekende lijsten. Duidelijk is, dat noch de specificatie noch de omvang van goede werken vast liggen. Die handelingen kunnen omvatten: het troosten van de rouwende, het begeleiden van de dode, het begeleiden van de bruid, het vrijkopen van gevangenen, het verzorgen en uitdelen van liefdadigheid, dat wil zeggen, het voorzien in levensonderhoud op sjabbat. In ieder geval: niet genezen! In de oordeelsrede van de Mensenzoon noemt Mattheüs eten geven, drinken geven, huisvesten, kleden, ziekenbezoek en bezoeken van gevangenen. Van belang is dat hier evenmin genezen wordt genoemd. Karakteristiek voor de Mattheaanse versie is evenwel de nadruk op het voorzien in direct levensonderhoud in een noodsituatie: eten, drinken, kleding, huisvesting.

We kunnen deze gegevens relateren aan een dispuut tussen de scholen van Hillel en Sjammai over de zorg voor levensonderhoud op sjabbat. We geven

${ }^{85}$ D. Flusser, 'Die Gesetzeswerke in Qumran und bei Paulus', in: Geschichte-TraditionReflexion. Festschrift für Martin Hengel zum 70. Geburtstag, H. Lancik/H. Lichtenberger/P. Schäfer (Hrsg.), Bd. I. Judentum, Tübingen 1996, pp. 395-403, m.n. pp. 399. Flusser wijst op het relatieve onderscheid dat bestaat tussen het bredere 'goede daden' of 'goede werken' en de geboden: 'Es scheint dass im Judentum bei den Werken ein Element von Freiwilligkeit besteht.' (401) De verzoenende kracht van specifieke 'werken' vinden we al in 1QS 9,3-5, zij het daar als werken van de wet en als kritiek op de Tempel; Zie ook Ben Sira 32,(35), 1-5. Dat er een zekere ruimte is tussen ह̌ $\rho \gamma \alpha$ $\kappa \alpha \lambda \alpha$ en de geboden blijkt ook uit Rom 2,7 ! 
dat dispuut in haar bredere redactionele context weer, aangezien die context wijst op de samenhang tussen fysiek welzijn en liefdadigheid:

(A) R. Sjimon ben Eleazar zei in naam van de School van Sjammai:

Men doodt geen luizen op Sjabbat.

Maar de school van Hillel staat het toe.

(B) En zo placht Rabban Sjimon ben Gamliel ${ }^{86}$ te zeggen in naam van de School van Sjammai:

(1) men deelt geen liefdadigheid uit ${ }^{87}$ aan de armen op Sjabbat in de synagoge ${ }^{88}$; zelfs niet om een weesjongen en een weesmeisje met elkaar te huwen.

(2) en men onderhandelt niet tussen man en vrouw,

(3) en men bidt niet voor een zieke op Sjabbat.

Maar het Huis van Hillel staat het toe.

T. Sjabbat 16,21-22 (ed. Lieberman p 79-80); B. Sjabbat 12a en 107b.

De eerste kwestie (A) betreft de vraag of je luizen mag doodmaken. Het doden van dieren op sjabbat is een bekend probleem in de oudere bronnen. ${ }^{89}$ Van belang is, dat hier niet de waardigheid van dierlijk leven, maar de heiligheid van de sjabbat de motivatie vormt. ${ }^{90}$ Voor de Hillelieten is het lichamelijke welzijn belangrijker dan de heiligheid van de sjabbat. Zo heeft ook de redactor van de Tosefta het begrepen, die dit dispuut onmiddellijk laat volgen door een dispuut over andere activiteiten die samenhangen met menselijk welzijn. De tweede controverse (B) bespreekt activiteiten op sjabbat, gericht op menselijk welzijn in het algemeen en levensonderhoud in het bijzonder: (1) liefdadigheid ten behoeve van een bruidschat voor weeskinderen; (2) huwelijksbemiddeling en (3) het bidden voor zieken. ${ }^{11}$ De paralleltekst in de Babylonische Talmoed laat zien dat men deze activiteiten opvat als een cluster van 'goede daden':

${ }^{86}$ Ms Erfurt, ms London en de eerste druk: Rabban Sjimon ben Eleazar. Ms München van de bavli leest R. Sjimon ben Eleazar in naam van Rabban Sjimon ben Gamliel'. Beiden leren vaker Sjammaitische tradities.

${ }^{87}$ Het is niet geheel duidelijk of met פטסקין 'uitdelen' of 'vaststellen'/'afkondigen' wordt bedoeld. De vertalingen verschillen op dit punt.

88 'op sjabbat' ontbreekt in ms. Erfurt, ms. London en de eerste druk.

${ }^{89}$ Jubileën 50:12. Zie Doering, Schabbat, p. 101. Zie B. Sjabbat 12a en 107b (R. Eliezer). Op naam van R. Hizqia in P. Sjabbat 1,3 (3b).

90 'Wie slangen en schorpioenen doodt op sjabbat, handelt niet in overeenstemming met de chassidiem' (B. Sjabbat 121b). Vergelijk de chassidische halacha in M. Berachot 5,1 (wat doe je als tijdens je gebed een slang nadert?). Over deze teksten Safrai, 'Teachings', p. 21. De functie van dieren in de analogieën en gelijkenissen van Jezus en de rabbijnen verdient nader onderzoek.

${ }^{91}$ De mogelijkheid dat Jezus bad voor de zieken en dat dit zou zijn toegestaan lijkt me geen begaanbare weg: geen van de teksten vermeldt een gebed, slechts een oproep aan de zieke zelf. 
(...) En R. Sjimon ben Eleazar zei eveneens in naam van R. Sjimon ben Gamliel: ${ }^{92}$ men onderhandelt niet voor de verloving van kinderen, noch (treft men voorbereidingen) voor kinderen om hen het boek te leren of hen een vak te leren, en men troost geen rouwenden, noch bezoekt men zieken op Sjabbat; woorden van het Huis van Sjammai.

Maar het Huis van Hillel staat het toe. B. Sjabbat $12 a^{93}$

Liefdadigheid voor de armen, vermeld in de Tosefta, ontbreekt. Zo ook het bemiddelen tussen man en vrouw. De Bavli voegt studie van de Tora toe, evenals de verplichting van de vader om zijn zoon een ambacht te leren. Opvallend is eveneens de toevoeging van het troosten van de rouwenden en het bezoeken van de zieken (vgl. Mt 25,36). ${ }^{94}$ Het troosten van de rouwenden en het bezoeken van de zieken behoren, zoals we zagen, tot de handelingen die gelden als גמילות חסד, gemillut chesed (liefdedaden). Studie van de Tora en onderricht in een vak treffen we vaker als een vast kluster aan met gemillut chesed en dat kan de Babylonische variant verklaren. ${ }^{95}$ Deze versie is zo meer toegesneden op de klassiek rabbijnse combinatie van studie van Tora en 'daden van liefde' zoals genoemd in M. Pea 1,1, waar beide worden genoemd als voorbeelden van 'dingen zonder maat'. ${ }^{96}$

De oorspronkelijke omvang en vorm van de Sjammaiitische restricties zijn niet vast te stellen, al verraadt de Bavli in vergelijking met de Tosefta een rabbiniserende interpretatie. Wel laten de teksten een duidelijke tendens zien. Met het onderhandelen voor of uithuwen van kinderen wordt de zorg voor weeskinderen bedoeld. Die zorg is een bekend bijbels motief. ${ }^{97}$ Het voorkomen

${ }^{92} \mathrm{Er}$ is in de tekstvarianten onduidelijkheid over de tradent: Sjimon ben Eleazar, Sjimon ben Gamliel of de eerste in naam van de tweede.

${ }^{93}$ MS München bevat elementen van de Tosefta en presenteert waarschijnlijk een harmoniërende lezing: 'Men deelt geen liefdadigheid uit in de gemeenschap, zelfs niet om een weesjongen aan een weesmeisje uit te huwen. Men onderhandelt niet voor de verloving van kinderen, noch (treft men voorbereidingen) voor kinderen om hen het boek te leren of hen een vak te leren, en men bezoekt geen zieken op Sjabbat.'

94 B. Sjabbat 12a bespreekt met welke woorden men de zieken mag troosten op sjabbat.

95 Zie B. Sjabbat 127a (R. Jochanan). Zie uitweidingen op de verschillende onderdelen in de Jeruzalemse Talmoed a.l. en commentaar in S. Lieberman, Tosefta Kifshuta. A Comprehensive Commentary on the Tosephta 1-8, New York 1955-1973, pp. 278-9.

${ }_{96}$ Het ontbreken van het uitdelen van liefdadigheid in de Bavli (maar zie Ms München!), dat niet tot het traditionele rabbijnse cluster studie - liefdewerken behoort, onderstreept dit.

${ }^{97}$ Ex 22,22 e.v.; 23,10 e.v.; Dt 14,29; 16,11,14; 24,17 e.v.; 26,12 e.v.; 27,19 . Gods oordeel klinkt wanneer die verplichting niet wordt gehouden: Jes 1,23 enz. Als vervloeking over de slechte 
van bedelarij bij weeskinderen geldt inderdaad als een primaire zorg bij de rabbijnen. ${ }^{98}$ Mogelijk beluisteren we ook in de prediking van Jezus een echo hiervan: 'En wie één zo'n kind bij zich ontvangt in mijn naam, ontvangt Mij' (Mt 18,4, vert. KBS 1995). ${ }^{99}$

Het gaat in het Huisdebat om het garanderen van levensonderhoud en zo het voorkomen van bedelarij. De halachische logica van beide versies van de Sjammaïtische positie is duidelijk: de heiligheid van de sjabbat heeft voorrang op 'goede werken', waaronder liefdadigheid. De Hillelieten leggen de prioriteit bij goede werken en staan deze dus toe. We constateerden dat het Mattheaanse $\ddot{\varepsilon} \xi \varepsilon \sigma \tau \iota v$ een equivalent is van het Hebreeuwse מתירן (matirin, toegestaan zijn).

Deze tekst is in de literatuur wel genoemd, maar haar halachische logica en daarmee haar belang is te weinig onderkend. ${ }^{100}$ Het antwoord van Jezus dat 'het is toegestaan goed te doen op sjabbat' biedt geen exacte parallel met de baraita maar vertoont conceptuele verwantschap met de visie van het Huis van Hillel dat specifieke 'goede daden', waaronder handelingen die gericht zijn op het tegengaan van acute armoede, doorgang vinden op sjabbat. ${ }^{101}$ In dat verband is het betekenisvol, dat zowel de Tosefta als Mattheüs spreken over deze handelingen in de 'synagoge', dat wil zeggen, als een verantwoordelijkheid van de verzamelde gemeenschap op sjabbat. Het uitdelen van liefdadigheid en het onderhandelen voor weeskinderen wijzen op de plicht van de gemeenschap armoede en bedelarij te voorkomen bij diegenen die niet in hun eigen levensonderhoud kunnen voorzien. ${ }^{102}$ De Sjammaieten benadrukken de

in Ps. 109, 9-10. Jes 58,7 (hongerigen, daklozen, naakten); Ez 18,7.16; Job 22,6 en 31, 17.19.21.31f (wezen!); Tobith 1,16; 4,16; Jesus Sirach 7,34; Henoch 9,1 (wezen!); 42,8; 63,1.

98 De zorg voor een weeskind berustte in eerste instantie bij een door de vader of door het hof aangestelde voogd: Z.W. Falk, 'Private Law', p. 518, in: The Jewish People in the First Century, vol. 1; CRINT l,l, Assen/Philadelphia, 1974. Rabbijnse teksten over de zorg voor weeskinderen in Billerbeck, Kommentar l, 774 (op Mt 18,5); Exkurs 22, nr. 3, p. 542 en Exkurs 23 (Die altjüdischen Liebeswerke), pp. 571-72.

${ }^{99}$ Mc 9,37/Lc 9,48. Vgl. Luz, Matthäus (19-25). Evangelisch-Katholischer Kommentar zum Neuen Testament l/3, Neukirchen/Vluyn 1997, p. 15.

100 Doering, Schabbat, p. 449 klassificeert deze activiteiten als 'Fromme Tätigkeiten'. Luz, Matthäus, p. 234 wijst op een zekere verwantschap van Jezus met de Hillelieten in B. Sjabbat 12a, maar hij expliciteert dit niet.

101 Dat is dus geen extrapoleren vanuit het beginsel van levensgevaar, zoals Kister, 'Plucking on the Sabbath', p. 40 meent.

102 Dat staat los van de vraag of we bij synagoge moeten denken aan de op een specifieke plek verzamelde gemeenschap of aan een apart bedehuis. Zie L. Levine, The Ancient Synagogue. The First Thousand Years, New Haven/London 2000, pp. 56-57 en p. 132. Levine verwijst tevens naar 
prioriteit van de heiligheid van de sjabbat, waarschijnlijk op grond van de redenering dat er geen acuut levensgevaar dreigt. De negatieve reactie van omstanders - waaronder mogelijk Farizeeën - is dan ook te begrijpen vanuit de verwantschap met de Sjammaitische visie dat de heiligheid van de sjabbat in deze situatie voorrang dient te krijgen.

Schematisch loopt de redenering van Jezus in Mattheüs als volgt:

situatie: $\quad$ Eigenaar in nood door dreigend verlies dier

oplossing: armoede voorkomen door dier te redden

situatie: $\quad$ Mens in nood door ziekte

oplossing: armoede voorkomen door ziekte te genezen

De gemeenschappelijke noemer is dat het in beide gevallen is toegestaan om op sjabbat primair levensonderhoud veilig te stellen. De a fortiori redenering loopt dan ongeveer als volgt: Als geldt dat men een schaap, bron van levensonderhoud, mag helpen wanneer men dat dreigt te verliezen, dan geldt des temeer dat men een mens, die zijn levensonderhoud dreigt te verliezen door ziekte, mag genezen. De verbindende en beslissende schakel in de overgang van licht (dier) naar zwaar (mens) is de acute bedreiging van armoede. Positief gesteld: de verantwoordelijkheid van de gemeenschap, ook op sjabbat acute armoede te bestrijden.

De a fortiori redenering in Mattheüs blijft gekunsteld, daar ze opereert met een flankerende, kwalificerende gelijkstelling: schaap en hand fungeren als bron van levensonderhoud. Niettemin is een zijdelingse a fortiori niet onbekend en biedt onze verklaring een soepeler duiding van de analogie dan eerder aangedragen oplossingen. Bovendien verklaart ze verschillende elementen in de Mattheaanse tekst. ${ }^{103}$

Onze uitleg vindt steun in een oude traditie bij Hiëronymus. Volgens het door hem aangehaalde 'evangelie van de Hebreeën' zou het hier immers gaan om

Mt 6,2, waar Jezus waarschuwt dat je, wanneer je 'barmhartigheid doet', je dit niet in de synagoge, dat wil zegge, publiek moet doen! Vergelijk P. W. van der Horst, 'Was de synagoge vóór 70 een plaats van eredienst op sjabbat?', Bijdragen 60 (1999) pp. 125-146.

${ }^{103}$ De kal wachomer kent inderdaad ook complexe varianten met een derde vergelijkingsfactor: L. Jacobs, 'Hermeneutics', in Encyclopedia Judaica 8 (1971) p. 367. De a fortiori redenering blijkt niet altijd een soepele of sluitende redenering. Prof. Dr. Judith Frishman wees me op B. Kiddoesjien 34b-35a. De Talmoed bespreekt hier het rabbijnse beginsel, dat vrouwen niet verplicht zijn positieve, tijdgebonden geboden te onderhouden. De soegja legitimeert dit met behulp van een over twee schijven lopende en logisch zwakke a fortiori redenering. Zie commentaar van David Kraemer, Reading the Rabbis, The Talmud as Literature, New York/Oxford 1996, pp. 97 en verder. 
een metselaar die door zijn zieke hand gevaar loopt, te moeten bedelen! De metselaar verzoekt Jezus hem te genezen zodat hij weer kan gaan werken. ${ }^{104}$ De twee sleutelelementen in onze uitleg, te weten de ziekte als bedreigend voor het levensonderhoud en de toelaatbaarheid om daarom op sjabbat te genezen en zo armoede en bedelarij te voorkomen, vinden steun in deze traditie. Duidelijk is, dat er ook voor Mattheüs sprake is van een conflict tussen twee positieve, theologische waarden: sjabbatsrust en 'goede werken'. De genezing zelf is, zoals we al zagen, de feitelijke bezegeling van het debat. Volgens een klassieke discussie in de babylonische Talmoed (B.Baba Metsia 59a) hebben wonderen geen gezag bij het beslissen van de halacha. Deze visie dient echter historisch gezien enigszins te worden bijgesteld: er zijn wel degelijk voorvallen waarin wonderen een specifiek standpunt bezegelen of onder kritiek stellen. ${ }^{105}$ De versies van Marcus en Lucas bieden ook op dit punt een ander accent: de genezing accentueert bij beiden een christologisch motief, te weten het gezag van Jezus over de sjabbat, al impliceert dat ook bij hen geenszins het opheffen van de sjabbat.

Of Mattheüs een oorspronkelijker versie van ons dispuut kende valt nog te bezien. De korte versie van het antwoord van Jezus, de in deze studie geboden logische samenhang van het antwoord en de relatieve afwezigheid van christologische elementen in de Mattheaanse versie kunnen wijzen op oorspronkelijkheid. Maar we dienen rekening te houden met de mogelijkheid, dat Mattheüs de overlevering interpreteerde in het licht van bestaande discussies in zijn gemeente. ${ }^{106}$

Hoe dan ook, onze analyse plaatst de typisch Mattheaanse elementen in een betekenisvol verband. De structuur van het dispuut en de terminologie bij Mattheüs verraden verwantschap met rabbijnse halachische logica: de

104 Hiëronymus, Comm. in Matth. 12,13, geciteerd in K. Aland (ed.), Synopsis Quattor Evangeliorum, editio 33. 13e. revidierte Auflage, Stuttgart 1985, p. 158 . Hieronymus vermeldt tevens dat velen dit evangelie het authentieke Mattheüs evangelie noemen. Luz, Matthäus, 240-241 ziet deze traditie als een 'spätere, legendäre Ausschmückung' van een Joods-christelijke gemeente om het 'Skandalon' van Jezus genezen op sjabbat te verzachten. Onze analyse plaatst deze traditie in een ander licht: heeft zij nog weet van het eigenlijke 'Anliegen' in dit debat?

${ }^{105}$ A.I. Baumgarten, 'Miracles and Halakah in Rabbinic Judaism', JQR 73/3 (1983) pp. 238-253.

106 Doering, Schabbat, p. 462: 'Der Judenchrist Mt nimmt die Frage der Heilung eines nicht lebensgefährlich Erkrankten am Schabbat aus dem Themenkreis 'Lebensrettung' heraus. Vermutlich tut er das auch vor dem Hintergrund einer sich zu seiner Zeit verstärkenden frührabbinischen Diskussion um das schabbatverdrängende Prinzip piqquah nepes.' We kunnen deze conclusie nu bijstellen: Mattheuis bespreekt in het dispuut de halachische spanning tussen sjabbat en goede werken. 


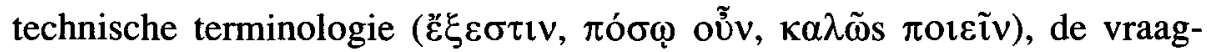
stelling en het korte, positieve antwoord van Jezus. Dat alles markeert een min of meer neutraal wetsdispuut. Het feitelijke genezen fungeert inderdaad secundair, als feitelijke bezegeling van een al beslecht dispuut. Onze hypothese verklaart eveneens de vermelding van één schaap ( $\pi \rho \beta_{\beta} \beta \tau$ cov $\varepsilon \tilde{v})$ als subtiele verwijzing naar de Nathanfabel en zo naar de nood van de eigenaar. De bijzondere locatie van het dispuut - de synagoge - hebben we tenslotte geduid vanuit de verantwoordelijkheid van de gemeenschap en de functie van de synagoge bij het verstrekken van liefdadigheid aan behoeftigen op sjabbat, althans volgens de Hillelitische halacha.

Bovenal hebben we gezien, dat het gebruik van vroeg-rabbijnse bronnen de impliciete logica van onze passage inzichtelijk maakt. Die logica behelst de spanning tussen twee positieve, bijbels-theologische concepten. Dat impliciete karakter is niet voorbehouden aan Mattheüs. Veel sabbatsdiscussies tussen de Huizen van Hillel en Sjammai, op het eerste gezicht zeer technische discussies over de toelaatbaarheid van specifieke handelingen, blijken uiteenlopende opvattingen te belichamen over de verhouding tussen de heiligheid van de sjabbat en de verantwoordelijkheid van de mens. Ook onze discussie in Mt 12,9-14 stelt aan de hand van een concrete casus de relatie tussen twee positieve geboden ter sprake: heiliging van de sjabbat en het verrichten van 'goede daden'. Jezus' antwoord dat het is toegestaan 'goede werken' te doen op sjabbat past in een bredere Mattheaanse samenhang die prioriteit hecht aan barmhartigheid, in casu 'goede werken' (Mt 23,23) en die hierin conceptueel verwant is aan de school van Hillel. Het blootleggen van verwantschap inhalachische logica impliceert niet dat de halacha identiek was. Maar beide teksten markeren een cruciale fase van de sjabbatshalacha. ${ }^{107}$

We hebben, tenslotte, gezien dat zowel in de Huisdiscussies als bij Mattheüs sprake is van een verantwoordelijkheid van de gemeenschap. Zowel in de optiek van Bet Hillel als die van Mattheüs is de heiligheid van de sjabbat niet belangrijker dan de - theologisch gemotiveerde - taak van de gemeenschap,

${ }^{107}$ Daarmee wijken we af van de conclusie van Doering, Schabbat, pp. 455-456: 'Aber er gibt, abgesehen vom Beispiel seiner Heilungstaten, keinen halachisch systematisierbaren Hinweis, wie der Schabbat in der von ihm proklamierten Perspektive zu begehen ist. Auch wird das, was hier 'Gutes tun' heisst, nicht von Tora oder Halacha her bestimmt.' Ook bij Bet Hillel blijkt 'goed doen' een keur aan mogelijkheden te behelzen, maar dat plaatst dit concept evenmin buiten de halacha! 
ook op sjabbat bepaalde goede werken uit te voeren. Bij de Hillelieten impliceert dat het voortzetten van de zorg voor wezen en armen op sjabbat. In dat perspectief is, volgens Jezus, ook genezen geoorloofd, als redding van levensonderhoud. ${ }^{108}$

(Summary: p. 367)

Eric Ottenheijm (1961) studeerde theologie en Talmudica aan de Katholieke Theologische Universiteit te Amsterdam (nu Utrecht). Hij is werkzaam als studiesecretaris voor de Katholieke Raad voor Israël, doceert in Amsterdam (HBO) en Utrecht (UU) en is als medewerker verbonden aan de B. Folkertsma stichting voor Talmudica te Hilversum. Momenteel voltooit hij zijn dissertatieonderzoek over de halachische disputaties tussen de Huizen van Hillel en Sjammai. Het onderzoek voor onderhavige studie werd mede mogelijk gemaakt door financiële ondersteuning van het Radboud fonds.

Adres: Volkerakstraat 52/2, 1078 XT Amsterdam (lieneric@worldonline.nl).

${ }^{108}$ K. Berger, Formgeschichte des Neuen Testaments, Heidelberg 1984, p. 309, noot c: 'Es geht nicht darum, durch die Argumente das Heilen zu rechtfertigen, sondern die Heilungen und die Argumente rechtfertigen die christliche Sjabbatpraxis überhaupt.' Berger gaat voorbij aan de positieve betekenis van het dispuut en het secundaire karakter van de genezing. Niettemin wijst hij terecht op de sociale betekenis van onze episode, maar scherper is die verwoord bij G. Theissen, Urchristliche Wundergeschichten. Ein Beitrag zur formgeschichtlichen Erforschung der synoptischen Evangelien, SNT 8, Gütersloh 1974, p. 249: 'Entscheidend ist nun, dass die urchristlichen Gemeinden solchen Ängsten nicht nur Wundergeschichten entgegensetzten, sondern auch dafür sorgten, dass kein Kranker wegen Erwerbslosigkeit hungern musste, dass sie sich überhaupt um Kranke kümmerten.' (curs. E. Ottenheijm) 